\title{
LIMINAL AO LIMINOIDE: EM BRINCADEIRA, FLUXO E RITUAL. UM ENSAIO DE SIMBOLOGIA COMPARATIVA $^{1}$
}

\author{
Victor Turner
}

\begin{abstract}
RESUMO
A partir da discussão da simbologia comparativa, que não deve ser confundida com a antropologia simbólica, ficando dela distante, objetiva-se tomar o símbolo como evento, e não como coisa, pois ele tem mais a ver com uma dimensão semântica, que remete ao significado na linguagem e no contexto. Desse ponto de vista, o símbolo ritual torna-se um fator de ação social, com um potencial criador ou inovador da ação humana. As ações de cultura expressiva possuem caráter de sistemas semânticos dinâmicos, ganhando e perdendo significados, pois "viajam através" de um rito ou obra de arte. Entre fenômenos liminares e liminoides, ritos e brincadeiras, pensam-se os subsistemas da cultura expressiva para refletir sobre as experiências de communitas e de flow (fluxo), quando observamos o envolvimento total da pessoa naquilo que ela faz.
\end{abstract}

Palavras-chave: Simbologia comparativa. Ritos. Brincadeiras. Liminal e liminoide. Cultura

\section{LIMINAL TO LIMINOID, IN PLAY, FLOW, AND RITUAL. AN ESSAY IN COMPARATIVE SYMBOLOGY}

\begin{abstract}
Starting from the discussion of comparative symbology, which should not be confused with symbolic anthropology, the objective is to take the symbol as an event, not as a thing, for it

\footnotetext{
${ }^{1}$ Este ensaio foi originalmente publicado em From Ritual to Theatre: The Human Seriousness of Play. New York, PAJ Publications, 1982. Versão em português autorizada por PAj Publications. Tradução de Herbert Rodrigues com a colaboração de Evelise Paulis. Revisão técnica de John Cowart Dawsey. Revisão e edição de Celso Vianna Bezerra de Menezes.
} 
has more to do with a semantic dimension, which refers to meaning in language and context. From this point of view, the ritual symbol becomes a factor of social action, with an innovative and creative potential of human action. Actions of expressive culture have character of dynamic semantic systems, gaining and losing meaning, since they "travel through" a rite or artwork. Among liminal and liminoid phenomena, rites and games, the subsystems of expressive culture are considered to reflect on the experiences of communitas and flow, when we observe the total involvement of the person in what he/she does.

Keywords: Comparative symbology. Rites. Plays. Liminal and liminoid. Culture.

\section{INTRODUÇÃO}

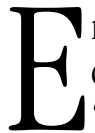
m primeiro lugar, vou descrever o que entendo por "simbologia comparativa" e como, em geral, esta se diferencia de diversas disciplinas como a "semiótica" (ou "semiologia") e a "antropologia simbólica", que estão envolvidas no estudo de noções de símbolos, signos, sinais, significações, índices, ícones, significados, significantes, inscrições, denotações etc. Gostaria de discutir, sobretudo, alguns tipos de processos socioculturais em que novos símbolos, verbais e não-verbais, tendem a se generalizar. Isso permitirá uma comparação entre os fenômenos "liminal" e "liminoide", noções que considerarei pormenorizadamente em seguida.

Segundo o Webster's New World Dictionary, simbologia é "o estudo ou interpretação de símbolos", e também a "representação ou expressão dos significados dos símbolos". 0 termo "comparativa" significa apenas que este estudo envolve a comparação como método, assim como, por exemplo, a linguística comparativa. Simbologia comparativa está mais próxima à semiótica ou semiologia (nos termos de Saussure e Roland Barthes) do que à "antropologia simbólica" numa cadeia e âmbito de dados e problemas. Semiótica é, como todos sabem, "a teoria geral dos signos e símbolos, em especial a análise da natureza e relações dos signos na linguagem, incluindo, sobretudo, os três ramos: sintático, semântico e pragmático".

1) Sintático: relacionamento formal dos signos e símbolos entre si, independentemente dos seus usuários ou das suas referências externas; organização e relação dos grupos, frases, orações, sentenças e estrutura de sentenças.

2) Semântico: relacionamento dos signos e símbolos com as coisas às quais eles se referem, isto é, seus significados referenciais.

3) Pragmático: relação dos signos e símbolos com seus usuários. 
Em minha análise de símbolos rituais, a sintaxe é forçosamente similar ao que chamo de "significado posicional"; a semântica é similar ao "significado exegético"; e a pragmática ao "significado operacional". Desde que foi definida como "ciência dos signos em geral", a semiologia parece ter maiores ambições do que a semiótica, por conta de ser esta restrita aos signos da linguagem, mesmo que Roland Barthes diga que "lingüística não é uma parte das ciências dos signos em geral... é a semiologia que é parte da linguística" (1967, p.11).

A Simbologia Comparativa não envolve diretamente os aspectos técnicos da linguística, tem mais a ver com os vários tipos de símbolos não-verbais em ritual e arte, embora admitidamente todas as linguagens culturais tenham importantes componentes linguísticos, transmissões ou "significantes". Contudo, está envolvida na relação entre símbolos, conceitos, sentimentos, valores, noções etc., associados entre si pelos usuários, intérpretes ou exegetas: em suma, tem uma dimensão semântica, pertence ao significado na linguagem e no contexto. Seus dados são principalmente retirados dos gêneros culturais ou subsistemas da cultura expressiva. Inclui tanto gêneros oral quanto literário, e deve-se levar em conta todas as suas atividades, combinando ações simbólicas verbais e não-verbais, tais como ritual e drama, e também gêneros narrativos, como mito, épica, fábula, romance e sistemas ideológicos. Poderíamos também incluir formas não-verbais, como mímica, escultura, pintura, música, balé, arquitetura, entre outras.

Mas a Simbologia Comparativa faz mais do que meramente investigar gêneros culturais abstratos da atividade social humana. Seria semiologia se o fizesse, cujo corpo de dados "deve eliminar os elementos diacrônicos o máximo possível" e coincidir com um "estado de sistemas, uma história transversal" (BARTHES, 1967, p.98). Em 1958, considerando os dados de rituais coletados durante meu trabalho de campo entre os Ndembu do Noroeste do Zâmbia, escrevi que "não se poderia analisar [esses] símbolos rituais sem estudá-los numa série no tempo em relação a outros 'eventos' [considerando um símbolo como 'evento', e não como 'coisa'], pois esses estão essencialmente envolvidos em processos sociais [e, eu acrescentaria, em processos psicológicos]. Entendo a performance ritual como uma fase distinta do processo social na qual os grupos se ajustam às alterações internas (se trazidos pelas pessoas ou facções dissidentes e conflitos de normas ou pelas inovações técnicas ou organizacionais), e se adaptam ao meio externo (social e cultural, assim como físico e biológico). Desse ponto de vista, o símbolo ritual torna-se um fator de ação social, uma força positiva no campo da atividade. Os símbolos são crucialmente envolvidos em situações de mudança social, estão associados aos interesses humanos, propósitos, fins e significados, aspirações e ideias, individuais ou coletivos, mesmo os que sejam explicitamente formulados ou deduzidos do comportamento observado. Por essa razão, a estrutura ou as propriedades de um 
símbolo ritual tornam-se aquelas de uma entidade dinâmica, pelo menos no seu apropriado contexto de ação." (TURNER, 1969, p.20).

Olharemos mais atentamente para essas "propriedades" em seguida. Mas gostaria de afirmar, uma vez que desde o começo considerei os símbolos como sistemas de dinâmica social e cultural, liberando e reunindo significados ao longo do tempo e alterando-se em forma, que não posso considerá-los meramente como "termos" numa lógica atemporal ou em sistemas cognitivos protológicos. Inegavelmente os gêneros especializados de sociedades complexas, tais como o filosófico, o teológico, sistemas de lógicas formais, símbolos e signos derivados de suas decomposições, adquirem essa "algébrica" ou qualidade lógica e podem ser efetivamente tratados nas relações de "oposições binárias" como "mediadores", e o resto, desnaturalizado pela primazia das atividades dos especialistas cognitivos. Mas os símbolos selvagens ("les symboles sauvages"), não apenas como aparecem na tradição ou nas culturas "tribais", mas também em gêneros de "atualizações culturais" da poesia, do drama, da pintura de sociedades pós-industriais, têm o caráter de sistemas semânticos dinâmicos, ganhando e perdendo significados - e significado num contexto social sempre tem dimensões emocionais e de livre-arbítrio - pois eles "viajam através" de um único rito ou obra de arte, deixados pela performance ao longo de séculos, e são objetivados nos efeitos produtivos dos estados psicológicos e do comportamento daqueles a eles expostos e obrigados a usá-los na comunicação com outros seres humanos. Sempre tentei ligar o meu trabalho à análise situacional, como, por exemplo, nos estudos sobre o processo de mudança da política tribal em Schism and Continuity (1957), com meu trabalho de análise das performances rituais.

Talvez isso tenha acontecido porque, com frequência, tenho focado o estudo de símbolos individuais nos campos semânticos e no fato processual tal como eles se movem através do cenário de uma performance ritual específica e reaparecem em outros tipos de rituais, e até se transferem de um gênero para outro, por exemplo, do ritual para um mito cíclico, para um épico, para um conto de fadas, para uma citação máxima num caso legal. Tal foco deixa o futuro semântico em cada símbolo, como ele era, com um final em aberto, em que a análise da totalidade dos símbolos, assumida a priori como um sistema ou uma gestalt, tratada como fechada, atemporal, e sincrônica, um corpus, ou coleção finita de materiais, tende a enfatizar as propriedades e relações formais de um símbolo dado e selecionar, da riqueza de seus significados, apenas aquela designação específica que o torna um termo apropriado em algumas oposições binárias, as quais são um bloco de construção relacional de um sistema cognitivo limitado. Binário e arbitrário tendem a se juntar, pois ambos estão num mundo atemporal de "significados". Tal tratamento, muitas vezes elegantemente sedutor, um frisson para nossas faculdades cognitivas, remove o conjunto total de símbolos do complexo, mudando continuamente a vida social, podendo ser opaco ou brilhante de desejo e 
sentimento, que é seu meio e contexto distintos, que se comunica com um rigor mortis dualístico.

Os símbolos, tanto como veículo perceptível sensorialmente (signifiants) quanto como um conjunto de "significados" (signifies), são essencialmente envolvidos em uma variedade múltipla, a variabilidade da vida, essencialmente, da consciência, do emocional e das criaturas voláteis que os empregam não apenas para dar ordem ao seu universo habitado, mas criativamente para fazer uso da desordem também, ambos pela superação ou redução em casos particulares e pelos significativos questionamentos de antigos princípios axiomáticos que se tornaram um freio sobre o entendimento e a manipulação das coisas contemporâneas. Por exemplo, a extravagância de Rabelais liberou inúmeras formas simbólicas escatológicas de posições para deveres e atributos desordenados em Gargantua e Pantagruel, desafiando a ordem do sistema escolástico teológico e do sistema filosófico - 0 resultado, paradoxalmente, foi disparar 0 obscurantismo hermético. Quando símbolos são enrijecidos na lógica operatória e subordinados às regras implícitas da sintaxe, por alguns de nossos investigadores modernos, aqueles que os levam muito a sério acabam se tornando cegos para 0 potencial criador ou inovador dos símbolos como fatores da ação humana. Os símbolos podem "instigar" tais ações e, em combinações situacionais variadas, canalizar suas direções pela saturação de metas e significados com afeto e desejo. A simbologia comparativa tende a preservar a capacidade lúdica, a capturar o símbolo em movimento, e então dialogar e "atuar" com suas possibilidades de formas e significados. Faz isso contextualizando os símbolos nos campos concretos e históricos e de seus usos pelo "homem vivo" no modo como ele age, reage, transgride e interage socialmente. Mesmo quando o simbólico é o inverso da realidade pragmática, ele se mantém intimamente ligado a ela, afeta e é afetado, fornece uma figura positiva com os seus negativos, assim como delimita e obtém para o "cosmos" um novo território.

Mais próxima da questão do que a semiótica, a simbologia comparativa vai além da antropologia simbólica, nas suas pretensões de levar em conta não apenas materiais "etnográficos", mas também os gêneros simbólicos das chamadas civilizações "avançadas", as ditas sociedades complexas de larga escala industrial. Inegavelmente, esta ampla perspectiva força a voltar a si mesma noções, métodos, teorias e achados de especialistas de diversas disciplinas, das quais muitos antropólogos sabem um pouco, como a história, a literatura, a musicologia, a história da arte, a teologia, a história das religiões, a filosofia etc. Todavia, ao fazerem essas tentativas para estudar ação simbólica em culturas complexas, os antropólogos, que estudam símbolo principalmente em "tribos" ou mito agrário, ritual e arte, não fazem mais do que retornar a uma honrosa tradição de seus predecessores, como Durkheim e a escola da Année Sociologique, e Kroeber, Redfield e seus sucessores, como o Professor Singer, que examinou subsistemas culturais em oikoumenes (literalmente "mundos inabitados", usado por Kroeber para 
indicar complexos civilizatórios como o Cristianismo, o Islã, o Hinduísmo, a Civilização Chinesa etc.) e as Grandes Tradições.

No meu caso, passei a estudar os gêneros simbólicos em sociedades de larga escala influenciado pelas implicações do trabalho de Arnold van Gennep (que tratou essencialmente de dados de sociedades de pequena escala) em Rites de Passage, cuja primeira publicação em francês é de 1908. Embora van Gennep pareça ter a intenção de que o termo "rito de passagem" devesse ser usado para rituais de acompanhamento individual ou de mudança individual de status social e para aqueles casos associados às mudanças sazonais de uma sociedade inteira, seu livro se concentra em tipos antigos; e o termo tem sido usado quase que exclusivamente em conexão com os rituais de risco ("life-crisis"). Tentei reverter o recente uso de van Gennep em consideração a quase todos os tipos de ritos como tendo uma forma processual de "passagem". 0 que esse termo significa?

Van Gennep, como se sabe, distinguiu três fases em um rito de passagem: separação, transição, e reagregação. A fase de separação claramente demarca espaço e tempo sagrados de espaço e tempo profanos ou seculares (isto é mais do que apenas uma questão de entrar num templo - há de se acrescentar um rito que altera a qualidade do tempo também ou construa um domínio cultural que é definido como "fora do tempo", isto é, para além ou para fora do tempo que mensure os processos seculares e rotineiros). Isso inclui comportamento simbólico - especialmente símbolos de reversão ou inversão das coisas, relacionamentos e processos seculares - que representa o desligamento dos sujeitos-rituais (noviços, candidatos ou iniciantes) dos seus estatutos sociais anteriores. No caso dos membros de uma sociedade, implica se moverem coletivamente de tudo que é social e culturalmente envolvido em um ciclo agrário, ou de um período de paz quando contra uma guerra, de uma praga ou epidemia na comunidade, do estado ou condição sociocultural anterior para um novo estado ou condição, uma nova mudança da estação do ano.

Durante a fase intermediária de transição, chamada por van Gennep de "margem" ou "límen" (que significa "liminar" em Latim), o sujeito-ritual passa por um período e por uma área de ambiguidade, um rápido limbo social que tem poucos (embora muitas vezes sejam cruciais) atributos tanto nos procedimentos profanos ou na subsequência de estatutos sociais como nos estados culturais. Trataremos melhor dessa fase liminal em seguida.

A terceira fase, chamada por van Gennep de "reagregação" ou "incorporação", inclui fenômenos e ações simbólicas que representam o retorno dos sujeitos às suas novas, relativamente estáveis, bem definidas posições na sociedade como um todo. Essas submissões rituais do ciclo da vida geralmente representam um status realçado, um estágio para além do caminho da vida pré-fabricado culturalmente; para aquelas que 
fazem parte de um ritual sazonal ou do calendário, não envolvem nenhuma mudança no status, mas pode ser preparado ritualmente para aquelas séries de mudanças na natureza das atividades ecológicas e culturais a serem empreendidas e dos relacionamentos que terão com outros - todas essas boas participações para um específico quarto do ciclo produtivo anual.

Muitos ritos de passagem são (para os sujeitos individuais) eventos irreversíveis que acontecem apenas uma vez, enquanto que ritos do calendário são preparados todos os anos por todas as pessoas, embora, é claro, alguns possam frequentar ritos de passagem de um parente ou de amigos muitas vezes, até conhecer sua forma melhor do que os próprios iniciantes, como as senhoras que "nunca perdem um casamento" comparadas com os noivos nervosos em seu primeiro casamento. Já disse que os ritos de passagem iniciatórios tendem a "colocar as pessoas para baixo" enquanto que alguns ritos sazonais tendem a "colocar as pessoas para cima", ou seja, os iniciatórios humilham as pessoas antes de elevá-las permanentemente, enquanto que alguns ritos sazonais (cujos resíduos são os carnavais e os festivais) elevam aqueles com menos status transitoriamente, antes de retorná-los às suas condições permanentemente humildes. Arnold van Gennep diz que o esquema dessas três fases varia em tamanho e grau de elaboração em diferentes tipos de passagens: por exemplo, "ritos de separação são notórios em cerimônias funerárias; ritos de reagregação, em casamentos. Ritos de transição são importantes, em determinados momentos, na gravidez, no noivado e na iniciação". A situação é mais complicada nas diferenças regionais e étnicas, as quais ultrapassam os modelos tipológicos. Contudo, é raro não encontrar traços desse esquema de três fases nos rituais "tribais" ou "agrários".

A passagem de um status social para outro é frequentemente acompanhada por uma passagem paralela no espaço, um movimento geográfico de um lugar para outro. Isso pode tomar a forma de uma abertura de portas ou a travessia literal de uma liminaridade separada por duas áreas distintas, uma associada ao sujeito pré-ritual ou de status preliminar, a outra ao status pós-ritual ou pós-liminar. (0s "dois passos à frente" do recruta quando recebe sua primeira ordem servem como uma instância moderna de um movimento ritualizado de liminaridade.) Por outro lado, a passagem espacial envolve uma longa peregrinação e a travessia de fronteiras nacionais antes de 0 sujeito atingir seu objetivo, o santuário sagrado - onde ações paralitúrgicas podem replicar no microcosmo do esquema de três fases no próprio santuário. Às vezes esse simbolismo espacial pode ser o precursor de uma mudança real e permanente de residência ou da esfera geográfica de ação, como quando, por exemplo, uma garota Nyakusa ou Ndembu na África, após seu rito de puberdade, deixa sua terra natal para viver na terra do marido, ou em certas sociedades de caçadores nas que os jovens vivem com suas mães até 0 momento de seus ritos de iniciação para a fase adulta, depois disso passam a viver com outros caçadores da tribo. 
Esse tipo de pensamento persiste, talvez, na nossa própria sociedade, quando, em inúmeras organizações burocráticas de escala nacional, como o governo federal, uma corporação industrial, o sistema universitário etc., promoções de status e salário envolvem, geralmente, movimentos no espaço de uma cidade para outra, um processo descrito por William Watson num artigo do livro Closed Systems to Open Minds (editado por MAX GLUCKMAN, 1965) como "espiralismo" ["spiralism"]. Seria interessante estudar a fase "liminoide" entre deixar um posto para ocupar outro em termos de simbologia comparativa, considerando tanto o sujeito (seus sonhos, fantasias, leituras e entretenimentos favoritos) quanto aquilo que ele está deixando e agrupando (seus próprios mitos, tratamento de si etc.). Falaremos mais sobre isso e da distinção entre "liminal" e "liminoide" em seguida.

De acordo com van Gennep, uma fase liminal prolongada nos ritos de iniciação de sociedades tribais é frequentemente marcada pela separação física dos sujeitos rituais do resto da sociedade. Desta maneira, em certas tribos da Austrália, Melanésia e África, um garoto submetido à iniciação deve permanecer um longo período de tempo vivendo fora, separado da interação social normal da aldeia e da casa. Os símbolos rituais dessa fase, embora alguns representem uma inversão da realidade, caracteristicamente se dividem em dois tipos: aqueles de remoção e aqueles de paradoxo ou ambiguidade. Portanto, em muitas sociedades, os iniciantes liminais são muitas vezes considerados opacos, invisíveis, como o sol ou a lua em eclipse ou entre as fases da lua, o "lado escuro da lua"; são despidos de nomes e roupas, lambuzados com a terra utilizada pelos animais. São associados a oposições básicas como vida e morte, masculino e feminino, comida e excremento, simultaneamente, desde o momento em que mudam ou morrem para o seu antigo status ou vida, e começam a nascer e crescer numa nova condição. Bruscas inversões simbólicas de atributos sociais podem caracterizar separações; reduções e fusões de distinções caracterizam liminaridades.

Desta maneira, os sujeitos rituais nesses ritos sofrem um processo de "elevação", no qual signos de status preliminar são destruídos e signos de status não-liminar aplicados. Mencionei certos indicadores de liminaridade - ausência de vestimentas e nomes; outros signos incluem comer ou não comer alimentos específicos, desconsiderar a aparência pessoal, vestir uma roupa uniforme, às vezes independente do sexo. No meio da transição, os iniciantes são levados ao máximo possível de uniformidade, invisibilidade e anonimato estrutural.

Em contrapartida, os iniciantes adquirem um tipo especial de liberdade, um "poder sagrado" de docilidade, fragilidade e humildade. Conforme disse van Gennep:

Durante todo o noviciado, os laços ordinários, econômicos e jurídicos são modificados, por vezes rompidos. Os noviços ficam fora da sociedade, que deixa de ter poder sobre eles, especialmente porque são sagrados e santos 
[em termos de crenças indígenas], por conseguinte intocáveis e perigosos, como se fossem deuses. Deste modo, por um lado, os tabus, como ritos negativos, levantam uma barreira entre os noviços e a sociedade, por outro lado, esta fica indefesa contra os empreendimentos dos noviços. Explica-se, assim, do modo mais simples do mundo, um fato observado em numerosas populações e que permaneceu incompreensível para os observadores. Durante o noviciado é que os jovens podem roubar e saquear tudo como bem entender, ou alimentar-se e adornar-se às custas da comunidade (1960, p.114).

Os noviços estão, de fato, temporariamente indefinidos, para além da estrutura social normativa. Isso os enfraquece, pois não têm direitos sobre os outros. Mas também são liberados das obrigações formais. Tomam lugar numa fechada conexão com poderes não-sociais ou associais da vida e da morte. Daí a frequente comparação dos noviços, de um lado, com fantasmas, deuses, ou ancestrais, e; por outro lado, com animais e pássaros. Eles estão mortos para o mundo social, mas vivos para o mundo associal. Muitas sociedades produzem uma dicotomia, implícita e explícita, entre sagrado e profano, cosmos e caos, ordem e desordem. Em liminaridade, relações sociais profanas são descontínuas, antigos direitos e obrigações são suspensos, a ordem social parece estar virada de ponta-cabeça, mas em compensação os sistemas cosmológicos (como objetos de estudo sério) tornam-se de central importância para os noviços, que são confrontados pelos veteranos em ritos, mitos, música, instrução de uma língua secreta e vários gêneros simbólicos não-verbais, como dança, pintura, cerâmica, escultura de madeira, máscara etc., com estrutura e padrão simbólico que equivalem aos ensinamentos sobre a estrutura do cosmos e sua cultura como parte e produto dela, pelo menos como são definidas e compreendidas, implícita ou explicitamente.

A liminaridade envolve uma sequência complexa de episódios no espaço-tempo sagrado e pode, do mesmo modo, incluir eventos subversivos e lúdicos (ou jocosos). Os fatores da cultura estão isolados, pelo menos é possível fazer isso com símbolos multivocais (isto é, com a ajuda de símbolos-veículos - formas sensorialmente perceptíveis) como árvores, imagens, pinturas, danças etc., que são suscetíveis não de um único significado, mas de muitos. Os fatores ou elementos da cultura são recombinados em números muitas vezes grotescos, porque são variados em termos de possibilidade ou fantasiados no lugar de combinações experienciadas - assim um monstro disfarçado pode combinar características humanas, animais e vegetais de modo "inatural" [unnnatural], enquanto que as mesmas características podem ser diferentemente, mas igualmente "inaturalizadas", combinadas numa pintura ou descritas num conto. Em outras palavras, as pessoas liminares "brincam" com os 
elementos familiares e os desfamiliarizam. Portanto, as novidades emergem das combinações sem precedentes dos elementos familiares.

No encontro de 1972 da Associação Americana de Antropologia em Toronto, Brian Sutton-Smith tomou emprestado um termo que eu já havia aplicado para "liminaridade" (e outros fenômenos sociais e eventos), a saber, "anti-estrutura" (compreendendo isso como a dissolução normativa da estrutura social, com seus papéis, status, direitos e deveres) e relacionou-a a uma série de estudos experimentais feitos com jogos infantis de crianças de sociedades tribais e industriais. Muito do que disse 0 autor, mutatis mutandis, pode ser transferido de volta ao estudo de liminaridade em ritual tribal. Para ele, "A estrutura normativa representa o equilíbrio, a 'anti-estrutura' representa 0 sistema latente das alternativas potenciais, as quais novamente irão surgir quando requeridas pelas contingências do sistema normativo. Podemos chamá-la de segundo sistema, de sistema proto-estrutural, [disse] porque é a precursora de inovações das formas normativas. Essa é a fonte de uma nova cultura" (1972, p. 18-19).

Sutton-Smith, que recentemente examinou o continuum ordem-desordem em jogos (como o jogo infantil inglês ring-a-ring-a-roses ${ }^{2}$ ), em seguida diz que "podemos ser desordenados em jogos [e, adicionaria, nos rituais de liminaridade, assim como em fenômenos "liminoides" como carnavais, festas, Halloween etc.] porque temos ao mesmo tempo uma overdose de ordem e queremos incendiar [podemos chamar isso de "visão conservadora" da desordem ritual, como rituais de inversão, a Saturnália, entre outros], ou porque temos algo a aprender sendo desordenados" (SUTTON-SMITH, 1972, p. 17). 0 que mais me interessa na formulação de Sutton-Smith é que ele vê situações liminais e liminoides como cenários em que novos modelos, símbolos e paradigmas surgem, como um solo fértil de criatividade cultural. Esses novos símbolos e construções então retornam aos domínios e arenas "centrais" da economia e da política, suprindo-os com metas, aspirações, incentivos, modelos estruturais e raisons d'être.

Muitos já disseram, sobretudo os estruturalistas franceses, que a liminaridade, em especial os fenômenos "liminais", como mito e ritual da sociedade tribal, caracteriza-se melhor pelo estabelecimento de "regras implícitas da sintaxe" ou pelas "estruturas internas de relações lógicas de oposição e mediação entre elementos simbólicos discretos" do mito ou do ritual, como provavelmente pensou Claude LéviStrauss. Para mim, essa é a análise da cultura em seus fatores e em suas livres ou "lúdicas" recombinações em cada padrão possível, estranho, portanto, à essência da liminaridade, a liminaridade par excellence. Isso pode ser percebido se os estudos das fases liminais da maioria dos rituais forem atravessados temporal e culturalmente. Quando as regras implícitas surgem, limitando a possível combinação de fatores de

\footnotetext{
${ }^{2}$ Jogo em que as crianças seguram as mãos umas das outras e dançam em círculo cantando, como a ciranda no Brasil (N. T.).
} 
certos padrões convencionais, desenhos ou configurações, então penso que estamos vendo a intromissão da estrutura social normativa naquilo que é potencialmente e, em princípio, uma livre e experimental região da cultura, uma região onde não apenas novos elementos, mas também novas regras combinatórias podem ser introduzidas mais rapidamente do que no caso da língua. Esta capacidade de variação e experimento torna-se mais claramente dominante nas sociedades em que o lazer é marcadamente definido a partir do trabalho, especialmente em todas as sociedades moldadas pela Revolução Industrial.

Vários modelos levi-straussianos, tais como a negociação com as relações de lógicas de oposições ou metafóricas, a transformação da humanidade, da natureza para a cultura, o modelo geométrico com os dois esquemas de oposições utilizados para a construção do "triângulo culinário", cru/cozido:cozido/podre, parecem para mim aplicáveis principalmente para sociedades tribais e agrárias nas que o trabalho e a vida tendem a ser governados pelo ritmo sazonal e ecológico, cujas regras básicas de padrões culturais das gerações tendem a buscar o par binário "Yin-Yang", formas sugeridas pelas simples oposições "naturais", quente/frio, úmido/seco, domesticado/selvagem, macho/fêmea, verão/inverno, farto/escasso, direito/esquerdo, céu/terra, acima/abaixo, entre outros. A sociedade principal e as estruturas culturais modelam-se nesses similares princípios cosmológicos, que determinam inclusive a disposição das cidades e das vilas, 0 desenho das casas, a definição e a posição do espaço de diferentes tipos de terra cultivada. A análise do simbolismo espacial em relação aos modelos cosmológicos e mitológicos se tornou uma trivialidade no estruturalismo francês recentemente.

Não é de surpreender que a liminaridade não tenha escapado das garras desses fortes princípios estruturalistas. Em apenas certos tipos de jogos de criança e brincadeiras são permitidos alguns graus de liberdade porque são definidos como estruturalmente "irrelevantes", não "importantes". Quando as crianças são iniciadas na qualidade de adultos precocemente, portanto, as variabilidades e as responsabilidades de comportamentos sociais são drasticamente reduzidas e controladas. Os jogos deixam de ser pediátricos e tornam-se pedagógicos. Lei, moral, ritual, e até mesmo vida econômica, caem sobre as influências estruturais dos princípios cosmológicos. 0 cosmos torna-se uma onda complexa de "correspondências", baseadas em analogias, metáforas e metonímias. Por exemplo, o Dogon do Deste africano, de acordo com Marcel Griaule, Genevieve Calame Griaule, e Germaine Dieterlen, estabelece uma correspondência entre diferentes categorias de minerais e os órgãos do corpo. Os vários solos são concebidos como os órgãos do "interior de um estômago", pedras são consideradas "ossos" de um esqueleto, e pedaços de argila vermelha são ligados ao "sangue". Similarmente, na China medieval, diferentes modos de pintar árvores ou nuvens são relacionados a princípios cosmológicos diferentes. 
Desse modo, os símbolos encontrados nos rites de passage nessas sociedades, embora sujeitos a permutações e transformações nos seus relacionamentos, são apenas envolvidos entre si em sistemas repetitivos, cíclicos, relativamente estáveis. É a esses tipos de sistemas que a noção de "liminaridade" pertence. Quando usado em processos, fenômenos e pessoas das sociedades complexas de larga escala, seus usos devem ser metafóricos. Ou seja, a palavra "liminaridade", usada principalmente na fase da estrutura processual de um rite de passage, é aplicada para outros aspectos da cultura aqui em sociedades de escalas e complexidades ainda maiores. Para mim, isso é um divisor de águas em simbologia comparativa. 0 fracasso na distinção entre sistemas simbólicos e gêneros pertencentes à cultura que se desenvolveu antes e depois da Revolução Industrial pode gerar muita confusão nos tratamentos teóricos e nas metodologias operacionais.

Permita-me explicar. Apesar da imensa diversidade dentro de cada campo, sempre restará uma distinção fundamental no nível da cultura expressiva entre todas as sociedades de antes e todas as sociedades subsequentes à Revolução Industrial, incluindo as sociedades industrializadas do Terceiro Mundo que, embora predominantemente agrárias, representam, todavia, o paiol e o parque de diversões das sociedades industriais metropolitanas.

Os conceitos-chave aqui são trabalho, brincadeira (ou jogo) e lazer. Colocar uma ênfase explicativa diferente em cada um ou em qualquer uma dessas combinações pode influenciar o modo como pensamos sobre os conjuntos de manipulação simbólica, os gêneros simbólicos, nos tipos de sociedades que iremos considerar. Cada um desses conceitos é multivocal ou multivalente, tem muitas designações.

Tomemos o trabalho. Segundo o Oxford English Dictionary, "trabalho" significa: (1) gasto de energia, esforço, aplicação de força para determinado fim (que corresponde muito bem à versão preliminar do Webster: "aplicação física ou mental exercida para fazer alguma coisa; atividade com fins, faina, labuta"); (2) tarefa a ser realizada, materiais a serem usados na tarefa; (3) fazer coisas, realizar, obra realizada, livros ou composições musicais [não se aplica "trabalho" aos gêneros do domínio do lazer]; (4) meritorius act como oposto à fé ou graça; (5) emprego, especialmente a oportunidade de receber dinheiro pelo trabalho, ocupação laboriosa; (6) ordinário, prático (como em workaday) etc. [onde tiver ressonância com o secular, profano, pragmático etc.]. Agora, em sociedades "tribais", "não-letradas", "simples", "de pequena escala", o ritual, suas extensões e o mito são considerados "trabalho", é precisamente nesse sentido que os Tikopia chamam de "o trabalho dos deuses". Na sociedade hindu antiga também há o "trabalho divino". No terceiro capítulo de Bhagavad Gita (v. 14-15), encontramos uma conexão entre trabalho e sacrifício: "Da comida derivam todos os contingentes humanos, e a comida deriva da chuva; a chuva deriva do sacrifício e o sacrifício, do trabalho. Do Brahman surge o trabalho". 
Nikhilananda comenta que "trabalho" aqui se refere ao sacrifício prescrito nos Vedas, o qual prescreve sacrifício ou trabalho ("ação") para as "famílias". Os Ndembu chamam o que um especialista em ritual faz, de kuzata, "trabalho", e o mesmo termo em geral é aplicado ao que um caçador, um cultivador, um chefe e hoje um trabalhador manual faz. Até mesmo nas complexas sociedades agrárias associadas às cidades-estados ou feudos, de acordo com a documentação histórica, encontramos termos como liturgia que na Grécia pré-cristã se estabeleceu como "serviço público aos deuses". "Liturgia" deriva do grego leos ou laos, "as pessoas", e "ergon", "trabalho" (cognato ao inglês antigo weorc, ao alemão werk, da base indo-européia, werg-, "fazer, agir". 0 grego organon, "ferramenta, instrumento", deriva da mesma base - originalmente worganon). 0 trabalho dos homens é, então, o trabalho dos deuses, uma conclusão que poderia ter iluminado Durkheim, se bem que poderia ter sido construído como implicado numa distinção fundamental entre deuses e homens, desde que os homens cooperassem em rituais para entrar melhor nessa relação recíproca de troca com os deuses ou com Deus - não foi à toa que "a voz da congregação foi a voz de Deus". Uma diferença foi construída entre criador e criatura.

Qualquer que seja o caso empírico, o que vemos aqui é um universo ou trabalho, um ergon- ou um universo organic, no qual a principal distinção é entre trabalbo profano ou sagrado, não entre trabalho e lazer. Por exemplo, Samuel Beal comenta, em Travels of Fah-Hian Sung-Yun, Buddhist Pilgrim from China to India (600 a.C. e 518 a.C.), [1964, p. 4], sobre o uso do termo "shaman" por Chi Fah-Hian: "A palavra chinesa shaman representa foneticamente o Sânscrito sramama, ou o Pali samana. A palavra chinesa é definida pelo significado 'diligente', 'laborioso'. A raiz sânscrita é 'sram' e quer dizer fatigado". (Ele se referiu ao povo de Shen-Shen, no deserto do Makhai, parte da região do deserto de Gobi) É, portanto, o universo do trabalho do qual todas as comunidades participam, como obrigação, não como opção. A comunidade como um todo caminha através do ritual inteiro, isso em termos de participação representativa ou total. Assim, alguns ritos, tais como aqueles de semeação, dos primeiros frutos, ou colheita, podem envolver a todos, homens, mulheres e crianças; outros são focados em grupos específicos, categorias e associações, como homens ou mulheres, velhos ou jovens, um clã ou outro, uma associação ou sociedade secreta ou uma outra. Já o trajeto ritual inclui a participação total da comunidade. Mais cedo ou mais tarde, ninguém é isento dos deveres rituais, do mesmo modo que ninguém é isento dos deveres econômicos, políticos e legais. A participação comunal, a obrigação, a passagem de toda a sociedade pela crise, coletiva e individual, diretamente ou por proximidade, são as marcas do "trabalho dos deuses" e do trabalho humano sagrado sem o qual o trabalho humano profano seria, para a comunidade, impossível de se conceber, embora sem dúvida, como a história tem cruelmente mostrado para aqueles conquistados pelas sociedades industriais, possível de viver ou, pelo menos, existir. 
Mesmo que se diga que esse tipo de "trabalho" não é trabalho, como conhecemos nas sociedades industriais, ambas as dimensões têm sagrado e profano e 0 elemento da "brincadeira". Na medida em que a comunidade e seus membros consideram-se com mestres ou "donos" do ritual e da liturgia, ou como representantes de ancestrais e deuses que ultimamente os "possuem", eles têm autoridade de introduzir, sob certas condições culturalmente determinadas, elementos de novidade ao longo do tempo socialmente herdados do depósito dos costumes rituais. A liminaridade, o período de reclusão, é uma fase que conduz peculiarmente às invenções "lúdicas". Talvez fosse melhor considerar a distinção entre "trabalho" e "brincadeira", ou melhor, entre "trabalho" e "lazer" (que inclui, mas excede o brincar sui generis) como artefatos da Revolução Industrial, e entender tais gêneros expressivo-simbólicos do ritual e do mito como sendo trabalho e brincadeira ou pelo menos como atividades culturais nas quais trabalho e brincadeira sejam intrinsecamente intercalados. Porém, com frequência, acontece que o posterior historicamente pode jogar luz sobre o anterior, especialmente quando há uma conexão sócio-genética demonstrável entre eles. Por isso há, sem dúvida, aspectos "lúdicos" da cultura em sociedades "tribais", especialmente em períodos liminais de iniciação prolongada ou em rituais baseados no calendário. Do mesmo modo, poderíamos incluir relações jocosas, jogos sagrados, tais como os jogos de bola da sociedade Maia antiga e da moderna Cherokee, charadas, zombarias, gozações e palhaçadas, contos do vigário ditos em tempos e lugares liminais, dentro ou fora do contexto ritual, e vários outros tipos.

A questão é que esses aspectos lúdicos e de brincadeira de mitos e rituais em sociedades tribais e agrárias são, conforme Durkheim, "de la vie sérieuse", isto é, são intrinsecamente conectados ao "trabalho" da coletividade em ações simbólicas performáticas e em objetos simbólicos manipulados de modo a promover e aumentar a fertilidade dos homens, das colheitas, dos animais domésticos e selvagens, a cura de doenças, a prevenir pragas, a obter sucesso em ataques, a converter meninos em homens e meninas em mulheres, a formar os chefes dos coletivos, a transformar pessoas ordinárias em xamãs, o "frio" em "quente", a assegurar a correta sucessão das estações do ano, da caça e da agricultura para os seres humanos, e assim por diante. Consequentemente, a brincadeira é levada a sério e tem que ser dentro dos limites. Por exemplo, no ritual dos gêmeos dos Ndembu, Wubwang'u, descrito no The Ritual Process, num episódio em que mulheres e homens se abusam verbalmente de modo altamente sexual e jocoso. Muitas ficções pessoais são inventivas, embora algumas sejam também estilizadas. Contudo, esse comportamento lúdico está no lugar do objetivo final do ritual - produzir descendência saudável, mas não muita de uma vez. Abundância é bom, mas abundância irresponsável é uma brincadeira boba. Portanto, brincadeiras entre homens e mulheres mantêm razoável fertilidade e reprimem insensata fecundidade. 
Brincadeira é engraçada, mas é também uma sanção social. A brincadeira pode até mesmo observar o "significado de ouro" ["golden mean"], que é uma característica ética das "sociedades cíclicas e repetitivas", mas não quando já desequilibrada pelas ideias inovadoras e por mudanças técnicas. Inovações técnicas são produtos das ideias, produtos que chamarei de "liminoides" (o "-óide" vem do grego -eidos, uma forma, um modelo, e significa "semelhante"; "liminoide", semelhante sem ser idêntico ao "liminar"), aquilo que Marx denomina "a superestrutura", e eu prefiro chamar de anti-, meta- ou protoestrutural. Superestrutural, para Marx, tem uma conotação de uma imagem invertida, ou até uma falsificação, uma mistificação do "estrutural" ou "infraestrutural" que é, nesses termos, a constelação de relações de produção, tanto na coesão como no conflito. Contrariamente, entendo "liminoide" como uma fonte independente e crítica - assim como os "trabalhos" liminoides de Marx, escritos no espaço recluso da biblioteca do Museu Britânico - e aqui observamos como em ações "liminoides" dos gêneros industriais de lazer pode repousar o caráter de "trabalho", - se bem que originalmente num "tempo livre" separado arbitrariamente pelo faça ["fiat"] do tempo do "trabalhismo" ["labor"] - tal como o liminoide pode ser um domínio independente de atividade criativa, não simplesmente uma imagem invertida, máscara ou capa de atividade estrutural dos "centros" do "trabalho social produtivo". Chamá-las de uma imagem invertida, é identificar as produções liminoides somente como apologia ao status quo político.

De fato, a "antiestrutura" pode generalizar e armazenar uma pluralidade de modelos alternativos para a vida, de programas utópicos, que são capazes de influenciar o comportamento nos papéis sociais e políticos principais (se autoritário ou dependente, no controle ou rebelado) em direção a uma mudança radical, na medida em que servem como instrumento de controle político. Como cientistas, estamos interessados em demarcar um domínio, sem ficar do lado de um ou outro grupo ou categoria que operem. Ciência teórica e ciência experimental são "liminoides", tomam lugar em "espaços neutros" ou áreas privilegiadas - laboratórios e estudos - deixados de lado pela produção central ou eventos políticos. Universidades, institutos, centros de pesquisa são cenários "liminoides" para todos os tipos de livre-pensar, comportamento cognitivo experimental, assim como formas de ação simbólica, assemelhando-se a alguns cenários encontrados em sociedades tribais, comparáveis às cerimônias de recrutamento em agremiações das universidades e das irmandades americanas, por exemplo. Isso, é claro, não significa que os produtos liminoides não tenham significância política: pense na Declaração dos Direitos dos Homens ou no Manifesto Comunista, por exemplo. Ou na República de Platão ou no Leviatã de Hobbes.

Mas olharemos essa noção de "liminoide" mais de perto e tentaremos distinguila da noção de "liminal". Para fazer isso corretamente, temos que examinar a noção de "brincadeira". A etimologia não nos diz muito sobre seus significados. Aprendemos que 
a palavra "brincar" ["play"] deriva do inglês arcaico plegan, "exercitar em si mesmo, se movimentar com vigor", e que o pleyen do holandês medieval, "dançar", é um termo cognato. Walter Skeat, no Concise Etymological Dictionary of the English Language (p.355), sugere que o plega anglo-saxão, "um jogo, esporte", é também (comumente) "uma luta, uma batalha". Ele considera, também, que os termos anglo-saxões são emprestados do latim plaga, "um golpe". Mesmo se a ideia de uma "dança ou luta ritualizada" toma conotação de "brincadeira", esse conceito multivocal tem seu próprio destino histórico.

Para o Webster's Dictionary, brincadeira é: (1) ação, movimento, ou atividade, especialmente quando livre, rápido, ou alegre (p.ex. o jogo dos músculos) - aqui, como em outras ocasiões, "brincar" é concebido como "alegre" em oposição ao "trabalho pesado", "livre" em oposição ao trabalho "necessário" ou "obrigatório", o caráter "rápido" em oposição ao cuidadoso, reflexo do estilo de rotina no trabalho; (2) "liberdade ou oportunidade de movimento ou ação"; (3) "atividade engajada numa diversão ou recreação" - aqui, de novo, estamos à beira da noção de atividade sem necessidade ou obrigações; (4) "alegria, piada (fazer uma coisa na brincadeira) enfatizando o caráter não sério de certos tipos de brincadeira moderna; (5) (a) "jogar um jogo", (b) "meio ou técnica de jogar um jogo" - aqui reintroduzindo a noção de que a brincadeira pode ser trabalho, ser séria com dimensões não sérias, e aumentar o problema das condições sob as quais "alegria" torna-se "técnica" e regras governantes; (6) (a) "uma manobra, movimento ou ato num jogo" (por exemplo, a humilhante "bola entre as pernas" ou o "chapéu" do futebol ou, então, uma específica jogada brilhante do time ou individual), (b) "uma mudança no jogo" (por exemplo, "há um jogador faltando no jogo"); (7) "0 ato de arriscar" (e aqui podemos pensar no "arriscar" de caráter divinatório em sociedades tribais ou feudais e, claro, a palavra "arriscar" deriva do inglês arcaico gamenian, "jogar", parecido com um termo do dialeto alemão gammeln, "divertir, fazer bem"; (8) "composição dramática ou performance", "drama", "o brincar das coisas" - claramente este termo preserva algo do primeiro sentido de "luta, batalha", assim como aquelas de "recreação", "técnica", e "partes (isto é, atos, cenas etc.) de uma peça teatral"; (9) finalmente, "brincar" pode significar "atividade sexual, jogos sexuais".

Aqui, de novo, podemos ver uma mudança de significado do sexo como "trabalho" procriativo (um significado persistente e frequentemente fornecido pelas doutrinas religiosas em sociedade tribais e feudais), a divisão da atividade sexual na "brincadeira" ou na "gozação", e na coisa "séria" da progênie paterna. As técnicas de controle de natalidade pós-industrial tornam essa divisão praticamente realizável e exemplificam a divisão entre trabalho e brincadeira trazida pelos sistemas modernos de produção, e pensada tanto "objetivamente" no domínio da cultura, quanto "subjetivamente" no indivíduo consciente e na consciência. A distinção entre "subjetivo" 
e "objetivo" pode ser, particularmente, um artifício de separação de trabalho e brincadeira. Ao "trabalho" é permitido ser realmente a adaptação racional dos significados para fins, "objetividade", enquanto que "brincadeira" é pensada como divorciada de sua essencialidade realmente "objetiva", e, no extremo disso, o inverso, é "subjetiva", livre dos constrangimentos externos, onde se "brincam" com toda e qualquer combinação de variáveis. Aliás, Jean Piaget, que fez muitos estudos de psicologia da brincadeira, considera isso como "um tipo de associação livre, sem acomodação às condições espaciais ou à significância dos objetos" (PIAGET, 1962, p.86).

Em estados ou fases liminais das culturas agrárias ou tribais - em rituais, mitos e processos legais - o trabalho e a brincadeira são fortemente distintos em muitos casos. De modo que, na Índia védica, de acordo com Alain Danielou (1964, p. 144), os "deuses [sura e deva, que são objetos de importante rituais de sacrifício] brincam. 0 nascimento, a duração e a destruição do mundo é o jogo deles". 0 ritual é tanto sério quanto brincalhão. Como Milton Singer apontou no seu livro sobre a Índia contemporânea, When a Great Tradition Modernizes (1972, p. 160), a "dança Krishna" num contexto urbano bhajana (um grupo que canta hino) é chamado lila, no qual os participantes "brincam" de ser "Gopis" ou o pastor de vacas que se "diverte" de várias maneiras com o Krishna, Vishnu encarnada, revivendo o mito. Mas o erótico brincar-amor de Gopis com Krishna tem implicações místicas, como o Cântico dos Cânticos - é mais uma vez sério e brincalhão, a "diversão" de Deus com a alma humana.

Agora vamos considerar a clara divisão entre trabalho e lazer que a indústria moderna produziu, e como isso afetou todos os gêneros simbólicos, do ritual aos jogos e à literatura. Joffre Dumazedier, do Centre d'Études Sociologiques (Paris), não é a única autoridade a sustentar que lazer "tem certos traços que são característicos apenas na civilização nascida da revolução industrial" (International Encyclopedia of Social Sciences, verbete "Lazer", 1968, p. 248-253; também Le Loisir et La Ville, 1962). Mas ele coloca o caso bem essencialmente, e estou de acordo com seu argumento. Dumazedier descarta 0 ponto de vista de que lazer existe em todas as sociedades e tempos. Em sociedades arcaicas e tribais, ele diz, "trabalho e brincadeira formam igualmente parte do ritual no qual os homens procuram comunhão com os espíritos ancestrais. Os festivais religiosos envolvem trabalho e brincadeira" (p. 248). No entanto, especialistas religiosos, tais como xamãs e homens da medicina, não constituíam uma "classe de lazer" no sentido de Thorstein Veblen, desde que realizassem funções mágicas e religiosas para toda a comunidade (e, como temos visto, xamanismo é uma profissão "diligente e laboriosa"). Similarmente, em sociedades agrícolas de história registrada,

0 ano de trabalho seguia um horário escrito em muitas passagens do dia e das estações: em tempo bom o trabalho é pesado, em tempo ruim afrouxa- 
se. 0 trabalho, nesse caso, tinha um ritmo natural, marcado pelo descanso, por músicas, jogos e cerimônias; foi sinônimo de rotina diária, e em algumas regiões começa quando o sol nasce, terminando quando o sol se põe... o ciclo do ano era também marcado por toda uma série de dias sabáticos e de festa. Os sabáticos pertenciam à religião; os dias de festa, portanto, eram frequentemente ocasiões de grande investimento de energia (para não mencionar de comida) e constituiu a observação ou oposição da vida cotidiana [muitas vezes caracterizado pela inversão simbólica e reversão de status]. Mas o aspecto cerimonial [ou ritual] dessas celebrações não poderia ser ignorado; eles retiraram da religião [definida como trabalho sagrado], não do lazer [como pensamos nos dias de hoje]... Esses foram impostos pelas necessidades religiosas... [e] a maioria das civilizações europeias sabia mais do que 150 trabalhadores desempregados por dia num ano (p. 249).

Sebastian de Grazia disse (1962) que as origens do lazer podem ser traçadas como o modo de vida desfrutado por certas classes aristocráticas no curso da civilização ocidental. Dumazedier discorda, dizendo que o estado do ócio dos filósofos gregos e a pequena nobreza do século XVI não podem ser definidos em relação ao trabalho, mas até certo ponto repõem trabalbo totalmente. 0 trabalho era feito por escravos, camponeses e servos. 0 verdadeiro lazer só existia quando complementava ou recompensava o trabalho. Isso não quer dizer que muitos dos refinamentos da cultura humana não vieram dessa aristocracia ociosa. Dumazedier acha que isso é significativo e que a palavra grega "não ter nada para fazer" (schole) também significa "escola". "Os cortesãos da Europa, depois do fim da Idade Média, inventaram e exaltaram o ideal do humanista e do cavalheiro" (p. 249).

"Lazer", então, pressupõe, "trabalho"; é um não-trabalho, até mesmo uma fase antitrabalho na vida da pessoa que também trabalha. Se fossemos nos satisfazer com uma terminologia nova, chamaríamos isso de anergic em oposição a ergic. 0 lazer surge, disse Dumazedier, sob duas condições. Primeiro, a sociedade cessa suas atividades por causa das obrigações rituais: algumas atividades, incluindo trabalho e lazer, tornam-se, pelo menos em teoria, sujeitas a escolhas individuais. Segundo, o trabalho com o qual as pessoas ganham a vida é "colocado ao lado de outras atividades; seus limites são não mais 'naturais' arbitrariamente - certamente, é organizado de modo definitivo, uma moda que pode facilmente ser separada, na teoria e na prática, do seu tempo livre". Apenas na vida social das civilizações industriais e pós-industriais encontramos essas condições necessárias. Outros teóricos sociais, radicais e conservadores, dizem que o lazer é um produto industrializado, racionalizado, burocratizado, de sistemas socioeconômicos de larga escala, com delimitação mais arbitrária do que natural do "tempo livre" ou "folga" do "trabalho". 0 trabalho é agora 
organizado pela indústria como sendo separado do "tempo livre", o que inclui, além do lazer, o atendimento às necessidades pessoais, como comer, dormir, o cuidado com a saúde e a beleza, assim como as obrigações familiares, sociais, civis, políticas e religiosas (que poderiam estar no domínio do continuum trabalho-brincadeira em uma sociedade tribal). 0 lazer é predominantemente um fenômeno urbano e quando este conceito começa a penetrar nas sociedades rurais é porque o trabalho agrícola tende a se tornar industrial, um modo de organização racionalizado, e também porque a vida rural está permeada pelos valores urbanos da industrialização - isso serve bem para 0 "Terceiro Mundo" de hoje, assim como para o interior rural de sociedades industriais estabilizadas.

0 tempo do lazer está associado a dois tipos de liberdade: "liberdade de" [freedom-from] e "liberdade para" [freedom-to], anunciando a famosa distinção de Iasiah Berlin. (1) liberdade de representa todo o conjunto de obrigações institucionais prescritas pelas formas sociais básicas, particularmente as organizações tecnológicas e burocráticas. (2) Para cada indivíduo, liberdade para significa o forçado, os ritmos cronologicamente regulados da fábrica e do escritório, e uma chance de recuperação, do prazer natural, e do ritmo biológico.

Lazer é também: (1) liberdade para entrar e até para gerar novos mundos simbólicos de entretenimento, esporte, jogos e diversões de todos os tipos. Além disso, (2) liberdade para transcender limitações sociais estruturais, liberdade para brincar... com ideias, fantasias, palavras (de Rabelais a Joyce e Samuel Beckett), pinturas (do Impressionista para a Pintura de Ação e Art Nouveau), e com relações sociais - com amizades, treinamento sensitivo, psicodramas, e muitos outros. Assim, mais do que ritos e cerimônias tribais e agrárias, o lúdico e o experimental são alargados. Em sociedades complexas, orgânico-solidárias, há evidentemente muito mais opções: jogos de habilidade, força e risco, que podem servir de modelo para comportamentos futuros ou modelos de experiências de trabalhos anteriores - agora vistos como vindos das necessidades do trabalho e de algo como escolhas para fazer. Esportes como futebol, jogos como xadrez, recreações como alpinismo podem ser difíceis, exaustivos, governados por regras e rotinas ainda mais rigorosas do que aquelas das situações do trabalho, mas, desde que opcionais, são parte de uma liberdade individual, de seu crescimento de autodomínio e até autotranscêndencia. Portanto, são imbuídos minuciosamente mais de prazer do que muitos daqueles tipos de trabalho industrial de cujos frutos e resultados os homens estão alienados. Lazer é potencialmente capaz de lançar poderes criativos, individual ou comunal, para criticar ou contrapor os valores dominantes da estrutura social.

É certo que ninguém está disposto a uma verdadeira atividade de lazer por necessidade material ou pelas obrigações morais e legais, como é o caso das atividades educativas, meios de vida, ou cumprimento das cerimônias civis e religiosas. Mesmo 
quando há um esforço, como num esporte competitivo, o esforço - e a disciplina do treinamento - é escolhido voluntariamente, na expectativa de um prazer que é desinteressado, não motivado por ganho e sem propósito utilitário ou ideológico.

Mas se isso é idealmente o espírito do lazer, a realidade cultural do lazer é obviamente influenciada pelo domínio do trabalho da qual foi dividida pela fatia da organização industrial. Trabalho e lazer interagem, cada participante individual em ambas as esferas, e os modos de organização de trabalho afetam os estilos do lazer e do passatempo. Vamos considerar o caso daquelas sociedades da Europa e da América do Norte cuja industrialização preliminar foi acompanhada e marcada pelo espírito que Max Weber chamou de "Ética Protestante". Esse meio ético, ou esquema de valores e crenças, que Weber pensou ser uma condição favorável para 0 crescimento do capitalismo moderno e racional, na minha visão, produziu efeitos no domínio do lazer completamente tão prováveis quanto os do trabalho.

Como todos sabem, segundo Weber, Calvino e outros reformadores protestantes ensinaram que a salvação é pura dádiva de Deus e não pode ser ganhada, sequer merecida, por um ser tão corrompido em sua natureza desde que Adão e Eva foram expulsos do Paraíso. A predestinação, de modo extremo, significa que ninguém poderia ter certeza de ser salvo ou ser de fato condenado. Isso ameaçou minar seriamente a moral individual e pôr de lado uma cláusula evoluída no nível popular da cultura, embora não pudesse ser feito de modo teologicamente hermético. Isso serviu para aquele que na graça de Deus e (invisível) entre os eleitos pelo decreto de Deus manifestasse realmente em seu sistemático comportamento o auto-controle e a obediência às vontades de Deus. Esses signos exteriores devem ser compreendidos pelos outros, e 0 homem pode reafirmar que é um dos eleitos e que não sofrerá do martírio eterno como um condenado. Mas o calvinista nunca estará seguro de que será salvo e assim dedica-se a um incessante exame das condições de sua alma interna e da vida externa para indicar evidências do trabalho da graça da salvação. De certo modo, o que, em história cultural, era previamente o "trabalho social dos deuses", o ciclo litúrgico e do calendário, ou melhor, suas penitências e provações, não suas festas, tornam-se "internalizadas" como o "trabalho" não-lúdico, sistematizado, do indivíduo consciente.

Uma outra ênfase calvinista foi a noção de vocação [calling] na vida. Ao contrário da noção católica de "vocação" como um chamado para a vida religiosa, emoldurado pelo tradicional voto de castidade, obediência e pobreza, o calvinismo sustenta que era precisamente a ocupação da pessoa comum que precisava ser relacionada com a esfera na qual ela serve a Deus através da dedicação e de seu trabalho. Trabalho e lazer foram feitos em esferas separadas, e "trabalho" torna-se sagrado, de facto, como uma arena na qual a salvação deve ser objetivamente demonstrada. Assim, um homem de posses deveria atuar como sendo um comissário das coisas mundanas, como José no Egito. Ele iria usá-las não para a luxúria, mas para 
uma melhor condição moral dele mesmo, de sua família, e de seus empregados. A "melhoria" implicou autodisciplina, autoexame, trabalho árduo, dedicação às obrigações e à vocação do escolhido, e a insistência de que aqueles sob sua autoridade deveriam fazer o mesmo.

Onde quer que a aspiração calvinista de teocracia tenha se tornado influente, como em Genebra ou na dominância transitória do puritanismo inglês, uma legislação foi introduzida para forçar os homens a melhorar seu estado espiritual através da lucratividade e do empreendimento. Por exemplo, o puritanismo inglês não afetou apenas a devoção religiosa com seus ataques ao "ritualismo", mas também reduziu 0 "cerimonial" (ritual "secular") ao mínimo em muitos outros campos de atividades, incluindo o drama, estigmatizados como "palhaçada". Seus atos tornaram ilegais as performances teatrais vinte e tanto anos depois das peças do teatrólogo Ben Jonson. Significativamente, entre os alvos de tal legislação, então, estavam alguns gêneros de lazer e entretenimento que foram desenvolvidos em ciclos aristocráticos e mercantilistas do período protoindustrial, como produções teatrais, masques ${ }^{3}$, alegorias, performances musicais e, claro, os gêneros populares de carnaval, festival, cantigas de balada ${ }^{4}$, e peças de milagre. Estas representaram o lado "lúdico" do continuum trabalho-lazer que foi formalmente capturado pela sociedade como um todo em um único processo, movendose através do sagrado e profano, das fases de solenidade e festividade sazonais.

Os calvinistas não quiseram "mais saber de bolos e de cerveja" - ou outros festivais de comida que pertenciam à brincadeira e ao trabalho dos deuses. 0 que eles buscavam era uma dedicação ascética para os rendimentos do empreendimento econômico; a sacralização do que era formalmente na maior parte profano, ou, pelo menos, subordinado a, auxiliava o paradigma cosmológico sagrado. Para Weber, quando as motivações religiosas do Calvinismo foram perdidas, após algumas gerações de sucessos mundanos, o foco no autoexame, na autodisciplina e no trabalho árduo da vocação do escolhido, mesmo quando secularizado, continuaram a promover a dedicação ascética dos lucros sistematizados, do reinvestimento dos salários e da lucratividade, que foram a aurora do capitalismo nascente.

Alguma coisa nesse caráter sistemático e vocacional da ética protestante atingiu até mesmo os gêneros do lazer industrial. Coincidindo com o termo, o lazer torna-se mesmo ergic, "a natureza do trabalho", mais do que ludic, a natureza da brincadeira. Desta maneira, temos uma séria divisão do trabalho no negócio do entretenimento, atuação, dança, canto, arte, literatura, composição etc., que se tornam "vocações"

\footnotetext{
${ }^{3}$ Peças escritas em verso, frequentemente com música e dança, populares na Inglaterra nos séculos XVI e XVII. (N. T)

${ }^{4}$ Uma música ou um poema que conta uma história, muito popular na Idade Média. (N. T)

5 "No more cakes and ale". (N. T)
} 
profissionalizadas. Instituições educacionais preparam atores, dançarinos, cantores, pintores e autores de "carreira". Num alto nível, nesses lugares cresceram, no final do século XVIII e em especial no século XIX, a própria noção de "arte" e suas várias modalidades, como uma vocação quase religiosa, com seus próprios ascetismos e dedicação total, de William Blake, através de Kierkegaard, Baudelaire, Lermontov, e Rimbaud, para Cézanne, Proust, Rilke, Joyce, para não mencionar Beethoven, Mahler, Sibelius etc.

Outro aspecto dessa influência da ética protestante sobre o lazer é na própria brincadeira. Como Edward Norbeck disse: "os antepassados da América acreditavam firmemente num conjunto de valores conhecidos como ética protestante. A devoção ao trabalho era uma virtude cristã; e a brincadeira, o inimigo do trabalho, era relutantemente permitida apenas às crianças. Mesmo nos dias de hoje, esses valores estão longe de serem extintos de nossa nação, e a velha admoestação de que brincadeira é obra do demônio permanece no pensamento secular. Se bem que a brincadeira tornou-se quase respeitável, é ainda alguma coisa que nos 'satisfaz' (como as relações sexuais), uma forma de relaxamento moral” (1971, p. 48-53). 0 esporte organizado (brincadeira "pedagógica") ajusta-se melhor à tradição puritana do que a brincadeira desorganizada de criança (brincadeira "pediátrica") ou a mera gozação, que é perda de tempo.

Contudo, as sociedades modernas industriais ou pós-industriais mudaram muito essas atitudes antilazer. 0 desenvolvimento tecnológico, a organização política e industrial dos trabalhadores, lideradas por profissionais liberais, e as revoluções em muitas partes do mundo tiveram o efeito acumulativo de produzir mais lazer no "tempo livre" das culturas industriais. Nesse lazer, gêneros simbólicos, tanto de entretenimento quanto de tipo instrutivo, se proliferaram. No meu livro, The Ritual Process, chamo alguns desses fenômenos de "liminais". Nesse sentido, questiono: Liminaridade é um rótulo adequado para esse conjunto de atividades e formas simbólicas? Certamente, há algumas considerações nas quais esses gêneros anergic partilham características com rituais ludergic e mitos (se contrastarmos estilos rituais hindus e judaicos) de culturas arcaicas, tribais e mais recentemente agrárias.

0 lazer pode ser concebido como entre-um-e-outro, um nem-esse-nem-aquele domínio, entre dois períodos do trabalho, ou entre atividades cívica, familiar e ocupacional. 0 lazer é etimologicamente derivado do francês antigo leisir, que derivou do latim licere, "está permitido", e que, bem interessante, tem uma base indo-européia *leik - "a venda, barganha", refere-se à esfera "liminal" do mercado, com suas implicações de escolha, variação, contrato - uma esfera que tem conexões em religiões arcaicas e tribais, com os deveres dos trapaceiros, tais como Eshu-Elegba e Hermes. A troca é mais "liminal" do que a produção. Assim como quando os membros de uma tribo fazem máscaras para se distinguirem dos monstros, juntam símbolos rituais 
díspares, invertem ou parodiam de modo profano a realidade em mitos e contos populares, então pegam os gêneros do lazer industrial, o teatro, a poesia, o romance, 0 balé, o cinema, o esporte, a música clássica, o rock, a arte pop etc., e brincam com os fatores da cultura, que se assemelham algumas vezes ao acaso, ao grotesco, improvável, surpreendente, chocantes combinações usualmente experimentais.

Mas eles fazem isso de modo muito mais complicado do que iniciações tribais de liminaridade, multiplicando gêneros especializados de entretenimentos artísticos e populares, cultura de massa, cultura pop, cultura popular, alta cultura, contracultura, cultura underground etc., como contra os gêneros simbólicos relativamente limitados à sociedade "tribal", e dentro de cada generosa permissividade da competência dos autores, poetas, dramaturgos, pintores, escultores, compositores, músicos, atores, comediantes, cantadores, roqueiros, em geral "fazedores", que fazem não apenas formas estranhas, mas também, e comumente, modelos, diretos e parabólicos ou esopianas, que são altamente críticos do status quo como um todo ou em parte. Claro, dada a diversidade como um princípio, muitos artistas, em diversos gêneros, também reforçam, justificam ou buscam legitimar a dominação social, os mores culturais e as ordens políticas. De modo que apontam em direções que tendem, mais intimamente do que as produções críticas, estar paralelas aos mitos tribais e rituais - eles são mais "liminais" ou pseudo ou mesmo pós "liminais", do que "liminoides".

A sátira é um gênero conservador porque é pseudoliminal. A sátira, expõe, ataca ou zomba daquilo que considera ser vício, tolice, estupidez ou abuso, mas seu critério de julgamento normalmente é uma moldura da estrutura normativa dos valores promulgados oficialmente. Portanto, trabalhos satíricos, como os de Swift, Castlereagh, ou Evelyn Waugh, frequentemente têm uma forma de "reversão do ritual", indicando que a desordem não é um substituto permanente da ordem. 0 espelho se inverte, mas também reflete 0 objeto. Isso não se desdobra de constituintes em ordem para se remoldar, muito menos aniquilar ou substituir aquele objeto. Porém, a arte e a literatura com frequência fazem precisamente essas coisas, pelo menos no reino da imaginação. As fases liminais das sociedades tribais invertem, mas nem sempre subvertem o status quo, a forma estrutural da sociedade; as reversões sublinham aos membros de uma comunidade que o caos é uma alternativa ao cosmos, assim eles estariam melhor ligados ao cosmos, isto é, à ordem tradicional da cultura, embora possam por algum tempo, ser caóticos em algumas folias saturnárias ou lupercárias, algumas manifestações carnavalescas ou orgias institucionalizadas.

Todavia, gêneros pretensamente de "entretenimento" da sociedade industrial são frequentemente subversivos, satíricos, fazem chacotas, são burlescos ou sutilmente colocam abaixo os valores centrais do essencial, a esfera do trabalho da sociedade, ou pelo menos de setores selecionados daquela sociedade. A propósito, a palavra "entreter" vem do francês arcaico entretenir, "deixar de lado", ou seja, criar um espaço liminal ou 
liminoide no qual performances podem ser realizadas. Alguns desses gêneros de entretenimento, tais como o teatro "clássico" ou "legítimo", são historicamente contínuos com o ritual, como nos casos das tragédias gregas ou o teatro japonês Noh, e possuem alguma coisa da seriedade sagrada, até mesmo a estrutura dos rites de passage de seus antecedentes. Contudo, diferenças cruciais separam a estrutura, a função, 0 estilo, o âmbito e a simbologia do liminal em rituais tribais e agrários e mitos que por vezes chamamos de gêneros "liminoides", ou de lazer, de formas e ações simbólicas nas sociedades complexas e industriais. Passo agora a discutir algumas dessas diferenças.

0 termo limen em si, "limiar" em latim, escolhido por van Gennep para aplicar a "transição entre", tem uma conotação negativa, uma vez que não é mais a condição passada positiva nem a condição futura positiva articulada. Parece, também, ser passivo já que é dependente das condições positivas, articulados, as quais medeia. Ainda sobre investigação, o que se acha na liminaridade são as qualidades positivas e ativas, especialmente onde o "limiar" é estendido e se torna um "túnel", quando o "liminal" se torna "cunicular"; este é o caso dos rituais de iniciação, com seus longos períodos de reclusão e o treinamento de noviços, rico em disposições de formas simbólicas e ensinamentos esotéricos. 0 "significado" na cultura tende a ser generalizado na interface entre estabilidades culturais e subsistemas, mesmo que os significados sejam institucionalizados e consolidados nos centros de tais sistemas.

A liminaridade é uma interface temporal cujas propriedades parcialmente invertem aquelas ordens já consolidadas que constituem qualquer "cosmos" cultural. Isso pode ser útil heuristicamente, se considerado em relação à liminaridade no mito/ritual de Durkheim na caracterização total da "solidariedade mecânica", que ele considerou como o tipo de coesão mais cooperativa, ação coletiva dirigida para as realizações dos objetivos do grupo, que melhor se aplica a sociedades pequenas, nãoletradas, com uma divisão do trabalho simples e pouca tolerância da individualidade. Durkheim baseou esse tipo de solidariedade na bomogeneidade dos valores e dos comportamentos, no forte constrangimento social e na lealdade às tradições e à família. As regras para a união são conhecidas e partilhadas. Agora o que frequentemente tipifica a liminaridade do ritual de iniciação em sociedades com solidariedade mecânica é precisamente 0 oposto disso: provações, mitos, máscaras, figuras, representações dos ícones sagrados aos noviços, línguas secretas, tabus sexuais e alimentares, que criam um estranho domínio no campo da reclusão no qual regularidades ordinárias de parentesco, na disposição das casas, leis tribais e costumes são reservados, onde o bizarro torna-se normal e onde, através do afrouxamento das conexões entre os elementos que estão habitualmente juntos em certas combinações, se embaralham e se recombinam em formas monstruosas, fantásticas e sobrenaturais, os noviços são induzidos a repensar - e bem - em experiências culturais sobre as quais eles não tinham dúvidas. Ensinam aos noviços que eles não sabiam o que achavam que sabiam. Sob a superfície da estrutura 
do costume havia uma estrutura profunda, cujas regras eles tiveram que aprender, através do paradoxo e do choque.

De diversos modos, os constrangimentos sociais tornam-se fortes, até mesmo sobrenaturais e irracionalmente fortes, assim quando os noviços são compelidos pelos seus superiores a submeterem 0 que na mente deles são tarefas desnecessárias por deveres arbitrários, serão punidos severamente se não obedecerem prontamente e, o que é pior, mesmo que tenham êxito. De outro modo, como no caso citado anteriormente no Rites de Passage de van Gennep, aos noviços são também concedidas liberdades sem precedentes - eles fazem pilhagens e invasões nas vilas e jardins, mexem com as mulheres, provocam as pessoas mais velhas. Inúmeras são as maneiras de colocar as coisas de cabeça para baixo, de parodiar os acordos do sistema normativo, de exagerar as regras em caricaturas ou satirizá-las. Os noviços são imediatamente colocados fora e dentro de um círculo previamente conhecido. Mas uma coisa deve ser certa: todos esses atos e símbolos são obrigatórios. Até mesmo a quebra das regras tem de ser feita durante o período de iniciação. Esse é um dos modos distintos em que o liminal é separado do liminoide.

No encontro de 1972 da Associação Americana de Antropologia em Toronto, muitos exemplos nas franjas das civilizações industriais das sociedades modernas foram citados (entre eles, o carnaval em St. Vincent nas West Indies, e a La Have Islands, Nova Scotia, citado por R. Abrahams e R. Bauman, 1972) que contêm algumas semelhanças às inversões liminais das sociedades tribais. Mas o que incomodava era como, mesmo nessas regiões "do interior", a opcionalidade dominava todo o processo. Por exemplo, quando as figuras mascaradas da La Have, geralmente rapazes ou homens recémcasados, conhecidos como belsnicklers, saem na véspera de Natal para provocar, irritar e ridicularizar os adultos, e também para assustar as crianças, eles batem nas portas e janelas das casas pedindo "permissão" para entrar. Porém, alguns moradores não permitem a entrada. Agora, não posso imaginar uma situação na qual os dançarinos mascarados de Ndembu, Luvale, Chokwe ou Luchazi (povos que tenho estudado e observado), que se revelam após a performance de um ritual, marcando o encerramento da primeira parte do período de reclusão e o início da outra no ritual de circuncisão chamado de Mukanda, se aproximando para dançar nas aldeias e ameaçando mulheres e crianças, tenham a entrada recusada. Eles nem sequer pedem autorização para entrar; eles tomam de assalto! Os belsnicklers "pedem" regalias aos moradores. Os Makishi (mascarados) entre os Ndembu exigem comida e presentes como um direito. A opção está impregnada nos fenômenos liminoides, a obrigação impera nos liminais. Um é todo brincadeira e escolha, uma espécie de entretenimento; o outro é uma questão profundamente séria, até temida, é exigente, compulsória, embora, de fato, o medo provoque risadas nervosas nas mulheres (que, se tocadas pelos makishi, acreditam contrair lepra, tornarem-se estéreis ou ficarem loucas!). 
De novo, em St. Vincent, apenas certos tipos de personalidades atraem-se pelo carnaval como foliões, aqueles que R. Abrahams, o investigador, descreve como "os grosseiros e o seguimento esportivo da comunidade", quem for "grosseiro e esportivo" terá a oportunidade de ser quando quiser, o ano todo - portanto, muitos podem pertinentemente personificar "desordem" versus "ordem" no carnaval. Aqui, de novo, o opcional é evidentemente dominante - as pessoas não precisam agir invertidamente como em rituais tribais; alguns, mas não todos, escolhem agir invertidamente no carnaval. 0 carnaval é diferente de um ritual tribal em que isso pode ser realizado ou evitado, executado ou meramente assistido, à vontade. É um gênero de lazer prazeroso, não uma obrigação ritual, é a brincadeira-separada-do-trabalho, e não brincadeira-etrabalho juntos como um sistema binário de tentativa comunal "séria" do homem.

Abrahams, em seu trabalho escrito com Bauman, desenvolve um ponto interessante, que realmente localiza o carnaval são vicentino na categoria de gênero-delazer-moderno, enfatizando que a maioria esmagadora dos "homens malvados e indisciplinados (macho-type)" que resolvem fazer inversões carnavalescas indicativas da desordem do universo e da sociedade, são pessoas desordenadas no temperamento e nas escolhas em muitas situações extracarnavalescas. Por outro lado, em ritual tribal, mesmo na normalidade, pessoas dóceis e "dentro-da-lei" são obrigadas a serem desordeiras em rituais-chave, desconsiderando seus traços particulares e temperamentos. A esfera da opção nessas sociedades é muito reduzida; até mesmo na liminaridade, onde o comportamento bizarro tão frequentemente é apontado pelos antropólogos, a sacra, as máscaras etc., emergem sob a guisa das "representações coletivas". Se em algum momento houve criadores e artistas individuais, eles foram subjugados pela ênfase "liminal" geral sobre o anonimato e a communitas, exatamente como tem sido com os noviços e seus mestres.

Mas, em gêneros liminoides da literatura e da arte industrial, e até da ciência (mais realmente homólogo ao pensamento liminal tribal do que a arte moderna), o grande público está debruçado sobre o indivíduo inovador, a única pessoa que ousa e opta por criar. Nessa ausência de ênfase na individualidade, a liminaridade tribal é vista não como a inversão da normatividade tribal, mas como sua projeção em situações rituais. Portanto, isso tem que ser modificado quando se olha para os atuais rituais de iniciação "em campo". Descobri que, entre os Ndembu, apesar de os noviços serem despidos de nomes, categoria profana, roupas, cada um surge como distinção individual e há um elemento de competitividade individual característico no fato de aos quatro melhores noviços nos termos de duração de performance de reclusão - na caça, resistência na provação, inteligência em respostas de adivinhação, espírito cooperativo etc., - serem dados títulos nos ritos que marcam a reagregação à sociedade profana. Isso indica, na minha opinião, que na liminaridade está a semente do liminoide, esperando apenas maiores chances no contexto sociocultural para surgir como um "candelabro" 
ramificado de muitos gêneros culturais liminoides. Se um tem que, como Tom Thumb, em poema infantil inglês, retirar uma preciosidade dialética de cada tipo de formação social, gostaria de aconselhar aos investigadores que se propõem a estudar o mundo que desaparece das sociedades "tribais" que olhassem para as fases liminais dos seus rituais de modo mais preciso, para localizar a incipiente contradição entre anonimato comunal e modos privados distintos dos principais entendimentos de crescimento sociocultural.

Tenho usado a noção de "antiestrutura" principalmente com referência às sociedades tribais e agrárias, para descrever a liminaridade e o que chamei de communitas. Quero dizer com isso não a reversão estrutural, uma imagem de espelho da estrutura socioeconômica "profana" do dia a dia, ou uma rejeição-fantasia das "necessidades" estruturais, mas a liberação das capacidades humanas de cognição, afeto, volição, criatividade etc., dos constrangimentos normativos incumbidos de ocupar uma sequência no status social, desempenhando uma multiplicidade de papéis sociais e sendo conscientemente membro de alguns grupos, como família, linhagem, clã, nação etc., ou de afiliação com algumas categorias de persuasão social como classe, casta, divisão sexual ou idade.

Os sistemas socioculturais caminham regularmente em direção à consistência de que os indivíduos só saem desses ganchos normativos em raras situações nas sociedades de pequena escala e não muito frequentemente em sociedades de grande escala. Apesar de tudo, as próprias exigências da estruturação, o processo de contenção de novos crescimentos em padrões ordenados ou estruturados tem seu calcanhar de Aquiles. Isso é o que acontece quando pessoas, grupos, conjunto de ideias se movem de um nível ou estilo de organização ou regulação de interdependência de suas partes ou elementos para um outro nível - há uma região interfacial - ou, mudando a metáfora, um intervalo, portanto breve, de margin ou limen, quando o passado é momentaneamente negado, suspenso, ou revogado, e o futuro ainda não começou, um instante de pura potencialidade quando tudo, como era, estremece no balanço (como a criatividade do meio-campista com todas as suas "opções", mas com o futuro bem sólido se movendo ameaçadoramente em direção a ele!).

Em sociedades tribais, em que se espera pela condução geral dos valores, comportamentos e regras da estrutura social, esse instante pode ser facilmente dominado ou contido pela estrutura social, mantido a salvo dos excessos inovadores, "cercado", como os antropólogos adoram dizer, pelo "tabu", "avaliação e balanço" etc. Assim, o liminal tribal, portanto exótico na aparência, nunca deve ser muito mais do que uma oscilação subversiva. Pois isso é logo colocado a serviço da normatividade. No entanto, vejo isso como um tipo de cápsula ou bolsa institucional que contém o germe dos desenvolvimentos sociais futuros, da mudança societária, de modo que tendências centrais de um sistema social nunca devem totalmente ter êxito em existência, nas esferas nas que lei, costume e os modos de controle social prevalecem. As inovações 
podem acontecer em tais esferas, mas frequentemente ocorrem em interfaces e liminaridade, então se tornam legitimadas em setores centrais.

Para mim, tais processos sociais relativamente "tardios", historicamente falando, como "revoluções", "insurreições", e até mesmo o "romantismo" na arte, caracterizado pela liberdade em forma e espírito, enfatizado em sentimento e originalidade, representam uma inversão da relação entre normativa e liminal em sociedades "tribais" e outras essencialmente conservadoras. Nesses movimentos e processos modernos, as sementes de transformação cultural, a insatisfação com o modo como as coisas estão culturalmente e a crítica social, sempre implícita na liminal pré-industrial, tornaram-se situacionalmente centrais, não apenas um problema de interface entre "estruturas fixas", mas uma questão holisticamente relativa ao desenvolvimento. Assim, revoluções, bem sucedidas ou não, tornam-se a limina, com todas as suas insinuações iniciatórias, entre uma maior forma de distinção estrutural ou ordenações da sociedade. Ou seja, podemos usar "liminal" de modo metafórico, não no termo "primário" ou "literal" conforme disse van Gennep, mas esse uso pode nos ajudar a pensar sobre a sociedade global humana, para a qual todas as formações históricas e sociais específicas podem muito bem convergir. As revoluções, violentas ou não, podem ser a totalização das fases liminais para as quais a limina dos rites de passage tribais foi meramente adivinhaç̧ão e premonição.

Esse poderá ser o ponto onde alimentamos, nas outras maiores variabilidades "antiestruturais", as communitas. (discuto os méritos e os deméritos falando sobre "antiestrutura", "metaestrutura", e "proestrutura" em seguida). Provavelmente, há em sociedades tribais um relacionamento mais próximo entre communitas e liminaridade do que entre communitas e estrutura normativa, embora a modalidade de interrelacionamento humano que é communitas possa "jogar" através dos sistemas estruturais de um modo tão difícil entre nós no presente para predizer seus gestos - essa é a base experiencial, acredito, da noção cristã da "graça alcançada" [actual grace]. Assim, nas oficinas, bairros, na sala de leitura, teatro, em todos os lugares as pessoas podem ser subvertidas de suas obrigações e direitos numa atmosfera de communitas.

Então o que é communitas? Tem uma base real ou é uma fantasia persistente do ser humano, um tipo de retorno coletivo ao útero? Tenho descrito essa maneira pela qual as pessoas veem, entendem, e atuam diante das outras (em The Ritual Process) como essencialmente "uma relação não mediada entre indivíduos concretos, históricos e idiossincráticos. Essa não é a mesma noção de communion que Georges Gurvitch descreve como "quando as mentes se abrem o máximo possível e menos acessíveis profundezas do "Eu" são integradas nessa fusão (que pressupõe estados de êxtase coletivo)" (1941, p. 489). Para mim, communitas preserva distinções individuais - isso não é regressão à infância, nem é emocional, nem "funde-se" na fantasia. 
Nas relações estruturais de pessoas sociais, elas são generalizadas por vários processos abstratos e segmentados em papéis, condições, classes, sexos culturais, convencionais divisões por idade, filiação étnica etc. Em diferentes tipos de situações sociais elas são condicionadas a desempenhar específicos papéis sociais. Não importa quão bem ou mal, desde que elas "façam de conta" que são obedientes ao conjunto de normas que controla diferentes comportamentos de modelos complexos conhecidos como "estrutura social". Por enquanto, isso tem sido quase o assunto principal das ciências sociais - pessoas desempenhando papéis e mantendo ou alcançando status. Sem dúvida, isso não cobre a grande negociação do tempo disponível, tanto no trabalho como no lazer. E, como extensão disso, é a autêntica essência humana que está envolvida aqui; para cada definição de papel leva-se em conta algum atributo humano básico ou capacidade e, indiscriminadamente, seres humanos jogam seus papéis de modo humano.

Mas, toda capacidade humana é aprisionada nessas poucas limitações, nesses quartos abafados. Mesmo quando dizemos que uma pessoa desempenha bem o seu papel, queremos dizer que ela atua com flexibilidade e imaginação. A noção de Matin Buber da relação Eu-e-Tu e do Nós essencial formado por pessoas que se movem em direção a uma meta comum de liberdade de escolha são percepções intuitivas de uma ordem não transacional ou de qualidade do relacionamento humano, de modo que as pessoas não necessariamente iniciam ações em direção aos outros na expectativa de uma reação que satisfaça seus interesses. Os antropólogos, indiscriminadamente, fogem muito dessas "pendências", eles lidam com "homens vivos", em seu altruísmo e empenho egoísta, nos microprocessos da vida. Alguns sociólogos, por outro lado, encontram segurança em questionários etnocêntricos, que, pela natureza do caso, distanciam o observador do informante e tornam pouco autênticas suas interações subsequentemente preservadas.

Em sociedades tribais e outras formações sociais pré-industriais, a liminaridade sustenta um contexto propício para o desenvolvimento dessas diretas, imediatas e totais confrontações de identidades humanas. Em sociedades industriais, isso acontece no lazer, e algumas vezes é ajudado pelas projeções da arte, em que esse modo de experiência dos sujeitos pode ser pintado, compreendido e, às vezes, realizado. A liminaridade certamente é um estado ambíguo de estrutura social, enquanto inibe toda satisfação social, provê uma medida de finitude e segurança; a liminaridade é, muitas vezes, o auge da insegurança, o avanço do caos no cosmos, da desordem na ordem, mais do que o meio de criatividade inter-humana ou satisfações e realizações transumanas. A liminaridade pode ser o reflexo da doença, do desespero, da morte, do suicídio, da quebra sem reposição compensatória da norma, e dos vínculos e laços sociais bem definidos. Isso pode ser anomie, alienação, angst, a árvore fatal das irmãs alpha de muitos mitos modernos. Em sociedade tribal esse é o domínio intersticial da bruxaria 
doméstica, da morte hostil e dos espíritos vingativos dos estranhos; nos gêneros de lazer das sociedades complexas, pode ser representado pelas "situações extremas" adoradas pelos escritores existencialistas: tortura, estupro, guerra, suicídio, tragédias, execuções etc.

A liminaridade é, ao mesmo tempo, mais criativa e mais destrutiva do que a norma estrutural. Em ambos os casos, criam-se problemas básicos para o homem social-estrutural, é um convite à especulação e à crítica. Mas onde é socialmente positivo representa, direta ou implicitamente, um modelo homogêneo de sociedade humana, uma communitas desestruturada, cujas fronteiras são idealmente partilhadas entre os seres humanos. Até mesmo quando duas pessoas acreditam na unidade de experiência, todas as pessoas são vividas por esses dois, mesmo se apenas por um instante, ao serem um. Sentimentos se generalizam mais facilmente do que pensamentos, é o que poderia parecer! A grande dificuldade é manter essa intuição viva - o entorpecimento regular não o fará, as repetidas uniões sexuais não o farão, a imersão constante na grande literatura não o fará, a reclusão iniciatória mais cedo ou mais tarde acabará. Chegamos ao paradoxo em que a experiência da communitas torna-se a memória da communitas, com o resultado de que a communitas nela mesma empenha-se em se repetir historicamente e desenvolve uma estrutura social em que as relações inicialmente livres e inovadoras entre os indivíduos são convertidas em relações de normas governadas entre personae social. Tenho consciência de que estou estabelecendo um outro paradoxo - quanto mais espontaneamente "iguais" ["equal"] as pessoas se tornam, mais distintas eles ficam entre si; quanto mais iguais [same] elas se tornam socialmente, menos elas se encontram individualmente. Agora quando essa communitas ou comitas é institucionalizada, o novo achado idiossincrático é legislado ainda em outro contexto de papéis e condições universalistas, cujos incumbentes subordinam a individualidade à regra.

Como disse no The Ritual Process: "A espontaneidade e a imediaticidade da communitas - como oposta ao caráter político-jurídico da estrutura (social) - podem raramente ser sustentadas por muito tempo. A própria communitas cedo desenvolve uma estrutura (social protetiva), em que relações inicialmente livres entre os indivíduos convertem-se em relações de normas governadas entre personae social". A chamada "norma" é um jogo, jogado com máscaras (personae), com um roteiro em que certos modos de comportamento "sem máscara" são definidos culturalmente como "anormais", "aberrantes", "excêntricos" ou "distantes". No entanto, communitas não representa a remoção das normas estruturais da consciência daqueles que participam dela; tampouco seus próprios estilos, numa dada comunidade, poderiam ser considerados como dependentes do modo pelo qual ela simboliza a obrigação, a negação, ou a inversão da estrutura normativa em que seus participantes são 
cotidianamente envolvidos. Até mesmo sua própria boa vontade de se converter em estrutura normativa indica sua vulnerabilidade para o desenvolvimento estrutural.

Observando os fatos históricos das communitas, identifico três formas distintas, mas não necessariamente sequenciais, que chamo de espontânea, ideológica e normativa. Cada uma delas tem certas relações com os fenômenos liminais e liminoides.

(1) A communitas espontânea é "uma confrontação direta, imediata e total das identidades humanas", estilo de interação pessoal mais profundo do que intenso. "Tem algo de "mágico" nela. Subjetivamente, há um sentimento de poder interminável". Quem de nós nunca conheceu esse momento em que pessoas compatíveis - amigos, cônjuges - obtêm um instante de entendimento lúcido mútuo no nível existencial, quando sentem que todos os problemas, não apenas os problemas deles, poderiam ser resolvidos, sejam emocionais ou cognitivos, se apenas o grupo é que sente (na primeira pessoa) como um "essencialmente nós" poderia sustentar sua iluminação intersubjetiva? Essa iluminação sucumbiria na disjunção da luz do dia seguinte, seria a aplicação de reações singulares e pessoais para a "glória" do entendimento comunal. Mas quando o humor, o estilo ou a "forma" da communitas espontânea está sobre nós, damos um destaque maior à honestidade pessoal, à abertura, e fechamos as pretensões. Sentimos que é importante relacionar-se diretamente com a outra pessoa como ela se apresenta aqui e agora, entendê-la de modo compreensível (não de maneira enfática que implica algumas recusas, alguma dissimulação do eu), livre de cuidados definidos culturalmente do seu papel, status, reputação, classe, casta, sexo ou outro nicho estrutural. Os indivíduos que interagem com outros ao modo da communitas espontânea tornam-se totalmente absorvidos num único evento sincronizado e fluido. Suas "vísceras" de entendimento da sincronicidade nessas situações são aberturas para a compreensão de tais formas culturais - hoje derivadas tipicamente da transmissão literária da cultura mundial, diretamente ou em traduções - como a união eucarística e o I Ching, que alargam a mútua participação mística (para citar Levy-Bruhl) de todos os eventos contemporâneos, como se apenas um tivesse o mecanismo de assegurar 0 "significado" subjacente de suas "coincidências".

(2) 0 que chamo de communitas ideológica é um conjunto de conceitos teóricos que descreve as interações da communitas espontânea. Aqui o olhar retrospectivo, "memória", já distanciou o sujeito individual da experiência comunal ou diádica. Nesse momento, o sujeito já examinou a linguagem e a cultura para mediar as antigas imediaticidades, um instante do que M. Csikszentmihalyi e J. MacAloon chamaram de "quebra de fluxo", isto é, uma interrupção da experiência no ato de fusão e da consciência (e centralização da atenção) que caracteriza o "resultado" supremo em ritual, arte, esporte, jogos e até mesmo em jogos de risco. 0 "fluxo" pode induzir à communitas, e communitas ao "fluxo", mas alguns "fluxos" são solitários e alguns 
modos de communitas separam a consciência da ação - especialmente em communitas religiosa. A quintessência não é o trabalho de equipe em fluxo, mas o "estarem" juntos, tendo como palavra operativa "ser" e não "fazer". 0 sujeito já começou a vasculhar o passado cultural herdado para modelos ou para elementos culturais desenhados dos escombros de modelos passados dos quais ele pode construir um novo modelo que irá, de modo balbuciante, reproduzir em palavras sua experiência concreta de communitas espontânea. Alguns desses conjuntos de conceitos teóricos podem ser expandidos e concretizados num modelo de sociedade "utópica", na qual todas as atividades humanas poderiam ser elevadas ao nível da communitas espontânea. Apresso-me em dizer que nem todos ou pelo menos não a maioria dos modelos "utópicos" são de "communitas ideológica". Utopia significa "não-lugar" em grego: a fabricação de utopias é uma irrestrita atividade de lazer "lúdico" do mundo moderno; tal fabricação, como a industrial, tende a firmar um ideal de estruturas político-administrativas como de primeira necessidade - incluindo altas hierarquias mais do que o mundo ou uma terra ou uma ilha poderia parecer se todos procurassem viver em communitas com seus vizinhos. Há muitas utopias hierárquicas, utopias conservadoras, utopias fascistas. Todavia, a utopia de communitas é encontrada de várias formas como um ingrediente central, conectado à noção de "salvação", em muitos trabalhos literários e de história da religião. "Seu Reino" (que sendo caritas, ágape, "amor", é um anti-reino, uma communitas) "vem".

(3) Finalmente, a communitas normativa é, mais uma vez, uma "perduração do sistema social", uma subcultura ou grupo que cuida e mantém as relações ou uma communitas espontânea numa base mais ou menos permanente. Para que isso aconteça, é preciso desnaturalizar, para uma communitas espontânea pesa mais a questão da "graça" do que a da "lei", para usar uma linguagem teológica. Seu espírito "sopra onde é ouvido" - não pode ser legislado, nem normalizado, desde que seja exceção, não lei; o milagre, não a regularidade, liberdade primordial, não anangke, a cadeia causal da necessidade. Mas, além disso, há algo sobre a origem de um grupo baseado até mesmo na communitas normativa que se distingue dos grupos que surgem na fundação de algo "natural" ou de "necessidade" técnica, real ou imaginada, tal com a relação do sistema produtivo ou um grupo imputado biologicamente conectado de pessoas, uma família, parentes ou linhagem. Algo de "liberdade", "liberação" e "amor" (para usar os termos do vocabulário comum da teologia ou filosofia política ocidental) aderem à communitas normativa, embora muito frequentemente os regimes rígidos retirem o que há de mais aparente nas experiências espontâneas da communitas. Esse rigor vem, sobretudo, do fato de que o grupo da communitas sente-se inicialmente bastante vulnerável aos grupos institucionalizados em volta dele. Ele desenvolve uma armadura institucional protetiva, armadura que se torna tão forte como a pressão que destrói a autonomia dos grupos primários que cresce proporcionalmente. Ele "se torna 0 
que ele vê". Por outro lado, se ele não "visse" seu inimigo, sucumbiria a ele. Esse dilema não é facilmente resolvido: é um crescimento, uma mudança, uma espécie de inovação que inventa novas ferramentas de pensamento, assim como de indústria e que explora novos estilos emocionais, como se se sucedesse através do tempo. A oposição ao antigo pode ser tão importante para a mudança como a inventividade do novo, assim como juntos constituem um problema.

Os grupos baseados na communitas normativa comumente surgem durante um período de reavivamento religioso. Quando uma communitas normativa é demonstravelmente um grupo de modo social dominante, alguém poderá testemunhar 0 processo de transformação de um momento pessoal e carismático em um sistema social repetitivo relativamente em curso. A contradição inerente entre a communitas espontânea e um sistema marcadamente estruturado é imensa, portanto qualquer aventura que tentar combinar essas modalidades será constantemente ameaçada pela clivagem estrutural ou sufocada pela communitas. 0 compromisso típico aqui - me refiro ao quarto capítulo do The Ritual Process para ilustrar casos históricos - tende a ser uma rachadura dos membros em facções opostas, uma solução que persiste apenas enquanto o equilibrio de poder é mantido entre eles. Normalmente, um grupo que primeiro organiza, e, além disso, estrutura-se metodicamente, prevalece política e parapoliticamente, embora os valores-chave da communitas sejam divididos por ambos os grupos, mas, colocados em suspenso pelo sucesso político, ele pode se tornar ressurgente no final. Assim, os Franciscanos Conventuais tiveram êxito em fazer com que os Franciscanos Espirituais fossem condenados pelos seus usus pauper, ou pobreza extrema, mas a Reforma Capuchina, iniciada cerca de três séculos depois em 1525, restaurou muitos dos ideais primitivos de pobreza e simplicidade franciscanas, que foram praticadas antes da cisão em Conventuais e Espirituais no século XIII.

Em termos simbológicos, distinguimos os símbolos dos sistemas políticojudiciários daqueles elaborados pelos sistemas religiosos. 0 usus pauper foi um símbolo político que marcou a clivagem faccional entre as duas alas franciscanas, enquanto "Minha Senhora Pobreza" - talvez uma variante franciscana do tema da "Santíssima Virgem" ou de "Nossa Senhora Mãe da Igreja" - foi um símbolo cultural que transcendeu as divisões políticas estruturais. A communitas tende a generalizar metáforas e símbolos que mais tarde se fragmentam em feixes e séries de valores culturais; é no reino da vida física (econômica) e do controle social (lei, política) que os símbolos adquirem caráter "socioestrutural". Mas é claro que os reinos cultural e socioestrutural se interpenetram e se sobrepõem do mesmo modo que os indivíduos concretos perseguem seus interesses, buscam atingir seus ideais, amores e desafetos, subjugam e obedecem um ao outro no fluxo da história. Não avançarei nesse ponto a questão de que o "método de caso-estendido", tendo o drama social como uma de suas técnicas, oferece um caminho fértil para estudar os símbolos e seus significados em 
eventos dentro do fluxo total dos eventos sociais, pois ainda me preocupo com os problemas das relações entre os símbolos, o liminal, o liminoide, a communitas e a estrutura social.

As communitas existem como um tipo de relação de "figura de base" com a estrutura social. As fronteiras de cada uma delas - na medida em que constituem modelos implícitos e explícitos de interação humana - são definidas pelo contato ou comparação de umas com as outras, apenas como a fase liminal de um rito de iniciação é definida pelos estatutos sociais em volta (muitos desses são acordos, inversões ou invalidações), e o "sagrado" é definido por sua relação com o profano - mesmo numa única cultura há muita relatividade, se A é "sagrado" para B pode simultaneamente ser "profano" para C, e "menos sagrado" para D. As situações relacionais prevalecem aqui, como um dos muitos outros aspectos do processo sociocultural. A communitas, no presente contexto do seu uso, então, é tida como existente mais em contraste do que em oposição à estrutura social, com uma alternativa, um modo "liberado" de ser socialmente humano, um modo tanto de ser destacado da estrutura social - e portanto periodicamente avaliando sua performance potencialmente - quanto de ser uma pessoa "distanciada" ou "marginal", mais apegada a outras pessoas dispersas - e assim às vezes avaliando uma estrutura social de performance histórica em comum entre eles. Aqui podemos ter temos uma satisfatória união do maldito julgamento pronunciado na estrutura normativa, suprindo modelos alternativos para ela.

Apesar de tudo, pelo fato de as fronteiras do modelo a-estrutural da interconexão descrita pela communitas ideológica estarem "idealmente partilhadas com aquelas da espécie humana" (e às vezes para além da "reverência da vida" genérica), aqueles que estão experienciando ou têm recentemente experienciado a communitas, muitas vezes, tendem a converter uma estrutura de interação social ou um conjunto de tais interações (envolvendo a primazia do comportamento do papel institucionalizado através da "livre vontade") numa direção, imediata e de total confrontação das identidades humanas, ou seja, numa communitas espontânea. A communitas tende a ser inclusiva - alguns chamariam de "generosa" - , a estrutura social tende a ser exclusiva, ou mesmo esnobe, gosta de distinguir entre nós/eles, do-grupo/fora-do-grupo, alto/baixo, melhores/piores. Isso leva a inclusão feita pela proselitização. Um quer fazer os Outros, Nós.

Um famoso caso na tradição ocidental é o pentecostalismo, quando pessoas de diferentes línguas e diferentes grupos étnicos reclamam, sob a inspiração do Espírito Santo, entender um ao outro completamente sub- ou translinguisticamente. Depois disso, o Pentecostes levou adiante a missionarização do mundo. A glossolalia de alguns pentecostais modernos conecta-se à noção de que, de fato, articula a fala e divide as pessoas em diferentes grupos linguísticos e nivela o "pecado", entre as pessoas de uma mesma comunidade de fala, disparates (arcaicos), facilidades da fala do amor e da virtude mútua. Mas essas conversões tentadas pelos indivíduos comunitários podem ser 
interpretadas não apenas pelas poderosas elites da estrutura social, mas também pela plebe, que se sente segura em obedecer a essas normas, como um tratamento direto de suas próprias autoridades e segurança, especialmente talvez por suas instituições-base de identidade social.

Assim, as tendências expansivas da communitas fazem explodir uma campanha repressiva dos elementos estruturalmente entrincheirados da sociedade, que conduz alternadamente em maior atividade, até mesmo oposição militante dos comunitários (cf. o histórico processo instalado em série por muitos movimentos milenaristas e renovadores); e assim por diante, sempre numa luta em espiral entre as forças da estrutura e os poderes da communitas - algo como N. Frye e D. Erdman (desenhado no símbolo de Blake) chamou de ciclo de Orc-Urizen - "Orc" representa a energia revolucionária e "Urizen", "o fazedor da lei e o tranquilizador da consciência" (S. Foster Damon), em si uma antecipação parcial da "circulação de elites" de Pareto, a elite revolucionária "como leão" sucedida pelas estratégias e táticas "como raposa" da manutenção do poder.

Apesar - e por causa da considerável extensão - desse conflito, a communitas desempenha funções importantes para a grande sociedade moderada e estruturada. No The Ritual Process, disse que: "Liminaridade, marginalidade e inferioridade estrutural são condições que frequentemente generalizam os mitos, símbolos, rituais, sistemas filosóficos e obras de arte. Essas formas culturais suprem os homens com um cenário de formas, modelos e paradigmas que são, de certo modo, reclassificações periódicas da realidade (ou, pelo menos, da experiência social) e da relação do homem com a sociedade, natureza e cultura. Mas não vão além da classificação (meramente cognitiva), desde que ela incite os homens a agir e pensar".

Quando escrevi isso, não havia feito a distinção entre o ritual érgico-lúdico de liminaridade e 0 gênero liminoide anérgico-lúdico da ação e da literatura. Em sociedades tribais, a liminaridade é frequentemente funcional, na maneira de ser uma obrigação especial ou uma performance requerida ao longo do trabalho ou da atividade; suas várias reversões e inversões compensam a rigidez ou as injustiças da estrutura normativa. Mas na sociedade industrial, a forma de rite de passage, apoiada num calendário e/ou modelada num processo orgânico de maturação e deterioração, não basta mais para toda a sociedade. 0 lazer proporciona a oportunidade de opções múltiplas, gêneros liminoides de literatura, drama e esporte não são concebidos como "antiestrutura" para a estrutura normativa cuja "antiestrutura é uma função auxiliar da estrutura alargada" (SUTTON-SMITHE, 1972, p.17). Preferencialmente são vistos, segundo Sutton-Smith, como "brincadeiras", ou seja, uma "experimentação com repertório variável" compatível com as diversas variações possíveis feitas pelo desenvolvimento tecnológico e o estágio avançado da divisão do trabalho (p.18). Os gêneros liminoides, para citar Sutton-Smith (que se referia à antiestrutura, um termo 
que tomou emprestado de mim, mas disse que o usei apenas no sentido de um sistema de manutenção), "não apenas toleram o sistema como existem, mantêm seus membros no mais flexível estado em relação ao sistema, e, além disso, em relação às possíveis mudanças. Cada sistema (prossegue Sutton-Smith) tem uma função adaptativa estrutural e antiestrutural. A estrutura normativa representa o trabalho de equilíbrio, a antiestrutura representa 0 sistema latente de alternativas potenciais das quais singularidades surgirão quando as contingências do sistema normativo forem requeridas". "Devemos corretamente chamar esse segundo sistema de protoestrutural, pois é o precursor de formas inovadoras. Essa é a fonte da nova cultura" (p. 18-19).

Nas ditas sociedades complexas de "alta cultura", o liminoide não é apenas retirado de um contexto de rite de passage, é também "individualizado". 0 artista solitário cria o fenômeno liminoide, a coletividade experiencia símbolos liminais. Isso não significa que o produtor de símbolos liminoides, ideias, imagens, faz apenas em ex nibilo; significa apenas que ele é privilegiado ao usar livremente sua herança social, de modo impossível para os membros de culturas cuja liminaridade é vista como sacrossanta.

Quando comparamos os processos e fenômenos liminais com liminoides, encontramos diferenças cruciais, assim como similitudes. Tentarei esclarecer. De modo preliminar e simples, eles fornecem algumas delimitações no campo da simbologia comparada.

(1) 0 fenômeno liminal predomina em sociedades tribais e agrárias, cujo modo de organização Durkheim chamou de "solidariedade mecânica", e que são dominadas pelo o que Henry Maine chamou de "status". Os fenômenos liminoides florescem em sociedades de "solidariedade orgânica", limitadas pelas relações reciprocamente "contratuais", e generalizadas pela revolução industrial, embora tenham surgido, provavelmente, em cidades-estados que acabaram se tornando impérios (do tipo grecoromano) e em sociedades feudais (incluindo não apenas os subtipos europeus encontrados entre os séculos X e XIV na França, na Inglaterra, em Flandres e na Alemanha, mas também em tipos feudais ou quase feudais menos "pluralísticos" no Japão, na China e na Rússia). Mas elas claramente se iniciaram no desenvolvimento da Europa Ocidental, nas sociedades do capitalismo nascente, nos primórdios da industrialização e mecanização, na transformação do trabalho em mercadoria e no surgimento da verdadeira classe social. 0 auge desse tipo de sociedade nascente foram os séculos XVII e XVIII - o clímax foi o "iluminismo", embora esse já tenha começado a aparecer na Europa Ocidental na segunda metade do século XVI, particularmente na Inglaterra, onde, logo em seguida, Francis Bacon publicou seu Novum Organum em 1620, obra que definitivamente uniu o conhecimento científico ao conhecimento técnico. Os fenômenos liminoides continuam a caracterizar as sociedades liberaisdemocráticas que dominaram a Europa e a América no século XIX e início do século XX, 
sociedades com sufrágio universal, predominância do legislativo sobre o poder executivo, parlamentarismo, pluralidade partidária, liberdade de organização para os trabalhadores e empresários, liberdade para formação de companhias de ações, organizações de cartéis e trusts, além da separação entre a Igreja e o Estado. Os fenômenos liminoides estão ainda altamente visíveis no Pós-Segunda Guerra Mundial em sociedades administradas e organizadas pelo capitalismo moderno como os Estados Unidos, a Alemanha, a França, a Grã-Bretanha, a Itália, o Japão e outros países do bloco Ocidental. Aqui a economia não é mais deixada mesmo ostensivamente para a "livre concorrência", mas é planejada tanto pelo Estado - geralmente nos interesses industriais e financeiros reinantes das altas classes médias - quanto pelos cartéis e grupos privados (nacionais e internacionais), com frequência com o suporte do Estado, que coloca sua considerável máquina burocrática a serviço deles. Os fenômenos liminoides também não estavam ausentes dos sistemas centralizados de estados coletivistas como a ex-União Soviética e a China, seguido pelas revoluções e pelas "democracias populares" do bloco da antiga Europa Oriental (com exceção da Iugoslávia, que primeiro se moveu em direção ao coletivismo descentralizado). Aqui as novas culturas tentavam sintetizar, como podiam, humanismo e tecnologia - não era uma tarefa muito fácil -, substituindo a lógica dos processos tecnológicos pelos ritmos naturais, enquanto procuravam despir-se desse caráter socialmente exploratório e propor que todos fossem sustentados pelo "gênio popular". Isso, portanto, com o coletivismo, tendia a reduzir as liberdades potencialmente ilimitadas dos gêneros liminoides para produzir formas agradáveis para as metas de integrar humanismo (de um ponto de vista de uma racionalidade moderna e ateia que sustenta a capacidade do homem de autopreenchimento, conduta ética etc., sem precisar recorrer ao sobrenatural) e tecnologia.

(2) Os fenômenos liminais tendem a ser coletivos, de acordo com o ritmo socioestrutural, biológico e do calendário, ou de acordo com processos de crise social, se esses resultados vierem de ajustamentos internos, adaptações externas ou medidas remediáveis. Assim, eles aparecem no que chamamos de "quebras naturais", disjunções naturais do fluxo natural e do processo social. São, então, executados pelas "necessidades" socioculturais, mas têm "liberdade" in nuce e a potencialidade de formação de novas ideias, símbolos, modelos e crenças. Os fenômenos liminoides poderiam ser coletivos (e quando o são, frequentemente foram derivados diretamente de antecedentes liminais), mas são mais caracteristicamente produtos individuais, embora tenham efeitos coletivos ou de "massa". Não são cíclicos, mas generalizados continuamente, embora em tempos e lugares fora do trabalho, em cenários designados para a atividade de "lazer".

(3) Os fenômenos liminais são centralmente integrados no processo social total, formando com todos os seus outros aspectos um todo completo e representando suas 
necessárias negatividades e subjetividades. Os fenômenos liminoides desenvolvem-se à parte da economia central e do processo político, ao longo das margens, nas interfaces e interstícios das instituições centrais - eles são plurais, fragmentados e de caráter experimental.

(4) Os fenômenos liminais tendem a confrontar os estudiosos à maneira das "representações coletivas" de Durkheim, ou seja, os símbolos tendo significados comuns, intelectual e emocional, para todos os membros do grupo. Eles refletem, na investigação, a história do grupo, suas experiências coletivas ao longo do tempo. Diferem das representações coletivas pré-liminal ou pós-liminal, pois são com frequência inversões, distinções, negações, antítese do cotidiano, representação coletiva "positiva" ou "profana". Mas partilham seu caráter coletivo e de massa.

Os fenômenos liminoides são mais idiossincráticos, peculiares, generalizados por indivíduos com nomes específicos e grupos particulares - "escolas", círculos e "panelas" - que competem entre si para reconhecimento geral e são tidos, no início, como ofertas lúdicas à venda no mercado "livre" -, pelo menos, nos fenômenos liminoides nas sociedades democrático-liberais do capitalismo nascente. Esses símbolos estão mais próximos ao pessoal-psicológico do que ao típico pólo "social-objetivo".

(5) Os fenômenos liminais tendem a ser, finalmente, funcionais por si mesmos quando aparentemente "inversos" para o trabalho da estrutura social, modos de fazer 0 social funcional sem muitas fricções. Os fenômenos liminoides, por outro lado, são frequentemente parte da crítica social ou até mesmo manifestações revolucionárias livros, peças teatrais, pinturas, filmes, que expõem injustiças, ineficiências e imoralidades das principais correntes das organizações e estruturas políticas e econômicas.

Em conjunto, nas sociedades modernas coexistem ambos os fenômenos num tipo de pluralismo cultural. Mas o liminal - encontrado nas atividades das igrejas, das seitas e dos movimentos, nos ritos de iniciação dos clubes, irmandades, ordens maçônicas e outras sociedades secretas etc. - não é mundial. Nem o são os fenômenos liminoides, que se generalizam em gêneros do lazer, da arte, do esporte, do passatempo, dos jogos etc., praticados por grupos particulares, categorias, segmentos e setores das sociedades de larga escala de todos os tipos. Mas para muitas pessoas, o liminoide ainda é sentido como mais livre do que o liminal, uma questão de escolha, não de obrigação. 0 liminoide é como uma mercadoria - na verdade, é uma mercadoria, que se seleciona e se paga -, mais do que o liminal, que exige lealdade e está colado aos membros ou aos desejos dos membros em alguns altos grupos corporados. Um trabalha para o liminal, o outro brinca com o liminoide. Poderá haver pressão moral para se ir à igreja ou à sinagoga, ao passo que no outro haverá filas para comprar bilhetes para ver a peça de Beckett, o show dos Rolling Stones, um jogo de futebol, um concerto da orquestra 
sinfônica ou uma exposição de arte. E se jogam golfe, praticam iatismo ou escalam montanha, precisam comprar equipamentos caros ou pagar para se tornar membros de clubes. É evidente que há todos os tipos de entretenimentos e performances liminoides "de graça" - Mardi Gras, Carnaval e diversas diversões domésticas - mas essas já têm algo de liminal sobre elas, com frequência são resíduos culturais de algum ritual liminal esquecido. Há também permanentes espaços e contextos "liminoides" - bares, boates, cafés, clubes sociais etc. Mas quando os clubes tornam-se exclusivos, tendem a generalizar ritos de passagem, com uma condição liminal de entrada ao domínio liminoide.

Realmente, ainda estou na fase exploratória até agora. Espero precisar melhor esse mapa simples, quase medieval, que desenrolei das regiões obscuras do liminal e do liminoide que se situam em torno da nossa confortável fortaleza sociologicamente conhecida, experimentada, provada e testada. Tanto o "liminal" como o "liminoide" são símbolos estudados na ação social, na práxis, e não inteiramente retirados da condição humana total. Isso significa estudar todos os domínios de cultura expressiva, e não apenas a alta cultura nem a cultura popular, o letrado e o não-letrado, a grande e a pequena tradição, o urbano e o rural. A simbologia comparativa nos ensina como "entrelaçar multidões" e generalizar sons intelectualmente gerados desse entrelaçamento. Devemos estudar os fenômenos sociais totais.

Gostaria de concluir considerando algumas relações entre communitas, "fluxo", o liminal e o liminoide. Antes, porém, explico o que Csikszentmihalyi e MacAloon entendem por "fluxo": "0 fluxo denota uma sensação holística presente no momento em que agimos com total envolvimento"; além disso, "é um estado em que as ações seguem outras ações de acordo com uma lógica interna que não necessita de uma intervenção consciente da nossa parte... Experimentamos isso como um fluxo unificado de um momento para o outro, no qual sentimos controlar nossas ações, em que há uma pequena distinção entre o eu e o meio; entre estímulo e resposta; ou entre passado, presente e futuro" (1972, mimeo). Alguns trabalhos recentes de Callois, Unsworth, Abrahams, Murphy (e de MacAloon e Csikszentmihalyi) focam várias formas de brincadeira e esporte (metagêneros liminoides de nossa sociedade), tais como alpinismo, escalada, futebol, hóquei, xadrez, natação em longa distância, handebal etc., nos quais o estado de fluxo pode ser experimentado. Csikszentmihalyi (1974) estende a noção de "fluxo", além da brincadeira, para a "experiência criativa" na arte e na literatura, e para experiências religiosas, e achados científicos e literários. 0 autor localiza seis "elementos", "qualidades" ou "características distintas" da "experiência de fluxo". São eles:

(1) A experiência de ação de fusão e consciência: não há dualismo no "fluxo"; enquanto um ator está consciente do que está fazendo, ele não pode estar consciente de que está consciente - se estiver, haverá comportamento rítmico ou um freio cognitivo. A 
autoconsciência o faz tropeçar. 0 "fluxo" percebido "de fora" torna-se "não-fluxo" ou "antifluxo". 0 prazer dá caminho ao problema, à preocupação e à ansiedade.

(2) Essa ação de fusão e consciência é possível graças à centralização da atenção num campo de estímulo limitado. A consciência é estreitada, intensificada e amarrada num foco de atenção limitado. "Passado e futuro são suspensos" - apenas 0 agora importa. Como isso é feito? Aqui as condições que normalmente prevalecem são "simplificadas" pela definição de algumas situações relevantes. 0 que for irrelevante é excluído. Os caminhos psicológicos de se fazer isso são as drogas e o álcool, que não "expandem" tanto assim a consciência, mas também a limitam e intensificam. A intensificação é o nome do jogo. Em jogos, isso é feito por regras formais e por significados motivacionais, como a competitividade. As regras de um jogo considera irrelevantes os "ruídos" que compõem a realidade social, o estímulo multiforme impingido em nossa consciência. Temos que obedecer a um conjunto limitado de normas. Assim, somos motivados a fazer bem pela estrutura intrínseca do jogo, de preferência, fazer o melhor do que os outros que se submetem às mesmas regras. Nossas mentes e nossas vontades são então desincumbidas das irrelevâncias e focam-se agudamente em certas direções conhecidas. As recompensas para o bom entendimento e a invencibilidade, quando atrelados ao conhecimento tático e técnico, completarão 0 foco. Mas para nossos autores "a coisa do fluxo" não é a regra, nem as motivações ou recompensas, isso envolve também "recursos internos", a "vontade de participar" (que como todos os fenômenos liminoides voltam-se ao voluntarismo; uma opção pela brincadeira), a capacidade de mudar a ênfase entre os componentes estruturais de um jogo ou de inovar ao usar as regras para generalizar performances sem precedentes. Mas é a limitação da regra e a motivação, a centralização da atenção, que incentivam a experiência de fluxo.

(3) A perda do ego é outro atributo do "fluxo". 0 "eu", que é normalmente 0 "corretor" entre a ação de uma pessoa e outra, simplesmente torna-se irrelevante - 0 ator é imerso no "fluxo", aceita as regras como ataduras que são também atadas em outros atores - o eu não é necessário para "barganhar" no que poderia ou não ser feito. As regras asseguram a redução do desviante ou do excêntrico em muitas manifestações do comportamento. A realidade tende a ser "simplificada a ponto de ser compreensível, definível e controlável" (1974, p.11). Essa permanência é válida, diz Csikszentmihalyi, para "rituais religiosos, performances artísticas e jogos". 0 auto esquecimento não significa perda de consciência. A consciência mental e cinética é, de fato, elevada, e não reduzida, mas seu efeito total é quebrado, como temos visto; um tipo especial de consciência do eu intrínseco é perdida. Mais uma vez, não há solitude, mero autismo, acerca da experiência. 0 fluxo atinge a natureza e os outros homens naquilo que Csikszentmihalyi chamou de "unidade de intuição, solidariedade, satisfação e aceitação". Todos os homens, e mesmo todas as coisas, são sentidos como um, 
subjetivamente, na experiência de fluxo - e muitos dados são trazidos para sustentá-la. A "participação mística" de Levy-Bruhl e a "experiência não-dualista" (Zen) de Suzuki são citadas, assim como os comentários de atletas e esportistas.

(4) A pessoa "em fluxo" encontra a si mesmo em controle de suas ações e do meio. Ela não saberá disso na hora do "fluxo", mas refletindo compreenderá que os seus conhecimentos foram equiparados às demandas feitas sobre si no ritual, na arte e no esporte. Isso a ajudará a "construir um autoconceito positivo" (p.13). Fora do "fluxo" é difícil atingir tal senso subjetivo de controle, devido à multiplicidade de estímulos e das tarefas culturais - especialmente, diria, nas sociedades industriais, com sua complexa e técnica divisão social do trabalho. Mas nos limites ritualizados de um jogo ou na elaboração de um poema, um homem ou uma mulher poderia copiar, se usassem a ocasião com habilidade e tato. Com controle, incômodo e receio se prossegue. Mesmo, como numa escalada na rocha, quando o perigo é real, o momento de "fluxo" inicia-se e a atividade é inscrita, o "deleite" do fluxo excede o senso de perigo e de problema.

(5) 0 "fluxo" normalmente contém coerência, uma demanda nãocontraditória para a ação, e supre os retornos não-ambíguos e claros para as ações de uma pessoa. Isso é acarretado pelas limitações da consciência num campo restrito de possibilidade. A cultura reduz o fluxo de possibilidades definidas de canais - xadrez, pólo, ação litúrgica, pintura em miniatura, exercício de ioga etc. Você poderá "se jogar" no design cultural de um jogo ou arte e saberá se foi bem ou não quando tiver terminado a rodada de atos predeterminados culturalmente - em caso extremo, se sobreviver, terá desempenhado adequadamente. Em outros casos, o público ou a crítica tem uma voz importante, mas se você for um verdadeiro "profissional", o julgamento final será seu, ao olhar para trás. Diferentes fluxos do cotidiano têm regras explícitas "que fazem as ações e as avaliações de ações não-problemáticas" (p.15). Assim, trapaças quebram o fluxo - você tem que ser um crente, mesmo que isso signifique temporária "suspensão de descrença disposta", isto é, levado (na onda liminoide) a acreditar que as regras são "verdadeiras".

(6) 0 "fluxo" é, finalmente, "autotélico", ou seja, não aparenta necessitar de metas ou recompensas fora dele mesmo. 0 fluxo é tão satisfatório quanto o ser humano pode ser - as regras particulares ou estímulos que desencadearam o fluxo, seja um jogo de xadrez ou um grupo de orações, não importam. Isso é importante para qualquer estudo do comportamento humano, se verdadeiro, pois sugere que as pessoas vão produzir culturalmente situações que vão iniciar o fluxo ou vão procurar individualmente fora de suas posições atribuídas em vida, se esses forem "fluxosresistentes". 
Csikszentmihalyi avança ao ligar a "teoria do fluxo" com a teoria da informação e a teoria da competência, mas não estou convencido dessas especulações. Penso que 0 autor magnificamente localizou e atribuiu qualidades para essa experiência - que teve que ser tratada fenomenologicamente, em primeiro lugar (embora depois pudéssemos ser mais "objetivos" com o padrão EEG ${ }^{6}$, as taxas de mudanças no metabolismo etc.).

Gostaria de dizer que aquilo que chamo de communitas simplesmente tem alguma qualidade de "fluxo", mas essa surgiria, e com frequência surge, desprevenida e espontaneamente - não necessita de regras para se desencadear. Na linguagem teórica, é mais uma questão de "graça" do que de "lei". Novamente, o "fluxo" é experienciado no indivíduo, ao passo que a communitas, sua base, é evidentemente entre indivíduos é 0 que todos acreditam e dividem, e seus produtos emergem do diálogo, no uso de palavras e de comunicação não-verbal, tais como o sorriso, o movimento do corpo etc. Para mim, o "fluxo" está no domínio do que chamo de "estrutura", a communitas é sempre pré-estrutural, embora aqueles que dela participam estejam saturado de estrutura - os seres humanos - desde a infância. Mas para mim o "fluxo" parece ser um dos modos em que a "estrutura" é transformada ou "liquidada" (como o famigerado martírio de sangue) na communitas de novo. Essa é uma das técnicas pelas quais as pessoas procuram o "reino perdido" ou "anti-reino" da direção, comunicação não-mediada entre as pessoas, mesmo que a severa subscrição esteja na trama onde a possível comunicação é induzida (a trama "mântrica", diria alguém).

Em sociedades anteriores à Revolução Industrial, o ritual tinha sempre uma qualidade de "fluxo" para as comunidades totais (tribos, clãs, linhagens, famílias etc.); em sociedades pós-industriais, quando o ritual dá lugar ao racionalismo e ao individualismo, a experiência de fluxo deslocou-se principalmente para os gêneros de lazer: a arte, o esporte, o jogo, o passatempo. Desde que o trabalho se tornou complexo e diversificado, as formas de prazer, o domínio dos gêneros de lazer, equivalentes ao opcional, paliativo ou medicinal, também se tornaram complexos e diversificados. Portanto, era o inverso do trabalho, se não na função, pelo menos na forma - mesmo que a função de muitos jogos seja para reforçar os paradigmas mentais que todos carregamos na mente e que nos motivam a levar adiante energicamente as tarefas que nossa cultura define como pertencente à esfera do "trabalho".

0 ponto aqui é que o ritual (incluindo sua fase liminal) em sociedades arcaicas, teocrático-carismáticas, patriarcais e feudais (até mesmo em pequenas cidades-estados que se tornaram impérios) e em certas instituições beneficentes - tal como o drama religioso - sustentou o principal padrão e mecanismo de fluxo cultural. Mas naquela época em que a esfera do ritual religioso se contraiu (como disse Durkheim), uma

\footnotetext{
${ }^{6} 0$ padrão EEG é um registro da atividade elétrica cerebral captado por eletrodos colocados no escalpo da cabeça. (N. T)
} 
multiplicidade (teoricamente) de gêneros não sérios, como a arte e o esporte (embora esses sejam mais sérios do que a ética protestante os definiu), têm, em grande medida, assumido a função de fluxo na cultura. A communitas é algo que não deve ser regido por regras - pode acontecer em qualquer lugar independente das regras. É como a "Testemunha" no pensamento hindu, que pode apenas olhar ou adorar, mas nunca agir (ou seja, não pode "fluir", nos termos dos jogos) sem mudar sua natureza.

Uma questão final: deixei de fora da communitas e do "fluxo" um traço essencial - o contentamento da experiência. É onde a análise dos símbolos se inicia os símbolos do xadrez, da arte impressionista, da meditação budista, da romaria mariana cristã, da pesquisa científica, da lógica formal, dos diferentes significados e das diferentes satisfações semânticas. Certamente, os processos de communitas e de fluxo estão imbuídos de significados dos símbolos que eles generalizam e que são por eles mudados. Serão todos os "fluxos" apenas um e os símbolos indicariam diferentes tipos e profundezas do fluxo?

\section{REFERÊNCIAS}

ABRAHAMS, Roger, and BAUMAN, Richard. "Ranges of Festival Behavior". Trabalho apresentado no Symposium on "Forms of Symbolic Inversion". AMERICAN ANTHROPOLOGICAL ASSOCIATION, Toronto, December 1, 1972.

BARTHES, Roland. Elements of Semiology. London: Jonathan Cape, 1967.

BEAL, Samuel. Travel of Fah-Hian and Sung-Yun. London: Susil Gupta, 1964. [Primeira Edição, 1869].

CSIKSZENTMIHALYI, Mihaly. Flow: Studies of Enjoyment. University of Chicago, PHS Grant Report, 1974.

. Play and Intrinsic Reward. Journal of Humanistic Psycology, 1975. [Páginas do manuscrito não publicado, 1972].

. Beyond Boredom and Anxiety: The experience of Play in Work and Games. San Francisco: Jossey-Bass, 1975.

DANIELOU, Alain. Hindu Polytheism. New York: Bollinger Foundation, 1964.

DUMAZEDIER, Joffre. Le Loisir et la ville. Paris: Editions du Seuil, 1962. . Article on "Leisure". In: SILLS, David (Ed.), Encyclopedia of the Social Sciences. New York: Macmillan and Free Press, p. 248-253, 1968. 
GENNEP, Arnold van. The Rites of Passage. London: Routledge and Kegan Paul, 1960. [Primeira Edição, 1909].

GRAZIA, Sebastian de. Of Time, Work, and Leisure. New York: Twentieth Century Fund, 1962.

GURVITCH, Georges. Mass, Community, Communion. Journal of Philosophy. August, 1941.

NIKHILANANDA, Swami. The Bhagavad Gita. New York: Ramakrisna-Vivekananda Center, 1969.

NORBECK, Edward. Man at Play. Play, a Natural History Magazine Supplement, p. 48-53, December, 1971.

PIAGET, Jean. Play, Dream, and Imitation. New York: Norton, 1962.

SINGER, Milton. When a Great Tradition Modernizes. New York: Prarger, 1972.

SUTTON-SMITH, Brian. "Games of Order and Disorder". Trabalho apresentado no Symposium on "Forms of Symbolic Inversion". AMERICAN ANTHROPOLOGICAL ASSOCIATION, Toronto, December 1, 1972.

TURNER, Victor. Schism and Continuity. Manchester: Manchester University Press, 1957.

. The Forest of Symbols. Ithaca: Cornell University Press, 1967.

.The Ritual Process. Chicago: Aldine, 1969.

. Dramas, Fields, and Metaphors. Ithaca: Cornell University Press, 1974.

WATSON, William. Social Mobility and Social Class in Industrial Communities. In: in GLUCKMAN, Max (Ed.), Closed Systems and Open Minds. Edinburgh: Oliver and Boyd, 1965. 